\title{
Su Altı Araçlarının Manevra Karakteristiklerinin Değerlendirilmesi-II: Akışkan Sınırlarının Etkileri
}

\author{
Oğuzhan Kırıkbaş ${ }^{1}$ Ömer Kemal Kınacı ${ }^{2}$, Şakir Bal ${ }^{3}$ \\ 1,2,3 Gemi İnşaatı ve Deniz Bilimleri Fakültesi, İstanbul Teknik Üniversitesi, İstanbul, TÜRKiYE \\ ${ }^{1}$ (sorumlu yazar), kirikbas17@itu.edu.tr, ORCID: 0000-0002-2504-8727 \\ ${ }^{2}$ kinacio@itu.edu.tr, 0000-0002-2956-9562 \\ ${ }^{3}$ sbal@itu.edu.tr, 0000-0001-8688-8482
}

ÖZET

Düşey düzlemde de hareket yeteneğine sahip olan su altı araçlarının manevra problemi aracın yörüngesini tanımlamak için tüm serbestlik derecelerinin matematiksel olarak dikkate alınmasını gerektiren zorlayıcı bir problemdir. Literatürde bu probleme çözüm getiren çalışmalar ağırlıklı olarak aracın derin dalmış durumunu dikkate alırlar. Bu çalışmalar problemin çözümünü kolaylaştıran sonsuz akışkan alanı varsayımına dayanırlar. Bunun yanında su altı araçlarının haberleşme, konum belirleme, solunum ve yanma havası ihtiyacını karşılama ve deniz tabanının sörveyi vb. gibi çeşitli operasyonel intiyaçlar sebebiyle akışkan sınırlarına yaklaşması kaçınılmaz bir zorunluluktur. Bu zorunluluk aracın manevra performansının sınır etkilerini de kapsayacak şekilde tahmin edilebilmesini gerektirir. Bu gereklilik ise problemin yapısının değişerek karmaşıklık seviyesinin artmasına ve dolayısıyla cevaplanması gereken yeni soruların ortaya çıkmasına sebep olur. Karşılıklı etkileşimler sebebiyle ortaya çıkan düzlem dışı kuvvetler, sevk parametreleri ile kontrol yüzeyleri üzerindeki etkiler ve tüm bu etkilerin manevra modelinde nasıl temsil edileceği gibi hususlar bu soruların en önemlilerindendir. Söz konusu soruların cevaplandırılabilmesi için öncelikle sınırların varlığı sebebiyle aracın manevra karakteristiklerinde gerçekleşen değişimlerin ayrı ayrı incelenip matematiksel olarak ifade edilmeleri gereklidir. Matematiksel olarak ifade edilen bu etkilerin manevra modelinde temsil edilmesi ise ikinci aşamayı oluşturur. Bu aşamada hidrodinamik katsayıların sınır akışlarını kontrol eden parametrelerin (Froude sayısı, derinlik, dip omurga mesafesi vb.) de bir fonksiyonu olacak şekliyle mevcut manevra modellerinde kullanımı literatürde yaygın kabul gören yaklaşımdır. Hareket denklemleri sınır etkilerini de dikkate alacak şekilde yeni bir manevra modeli türetilmesi seçeneği ise halihazırda kavramsal düzeyde kalmış bir yöntemdir. Operasyonel ihtiyaçların su altı araçlarının artan oranda akışkan sınırlarına yakın kullanımını gerektirmesi son yıllarda bu alandaki akademik çalışmalara olan ihtiyacı artırmıştır. Bu durum sınır etkilerinin farklı yönlerinin ayrıntılı olarak incelenmesi için araştırmacıları motive ederek bu alanda hatırı sayılır seviyede bir literatürün oluşmasına sebep olmuştur. "Su altı araçlarının manevra karakteristiklerinin değerlendirilmesi" ana başlığının ikinci bölümünü oluşturan bu çalışma kapsamında; mevcut literatür yatay ve düşey düzlem serbestlik derecelerinde serbest su yüzeyinin varlığı sebebiyle meydana gelen değişiklikler ile bu iki düzlemin karşılıklı etkileşimleri, serbest su yüzeyinin takıntılar ile karşılıklı etkileşimi ve sevk sistemi üzerindeki etkileri ve deniz tabanının etkileri başlıkları altında sınıflandırılmıştır. Bunun yanında bu etkilerin manevra modellerinde temsil edilebilmesi için gösterilen gayretlere ve sınırların varlığının problemin sayısal ve deneysel analizine getirdiği ilave zorluklara da yer verilmiştir. Böylece konu hakkında genel bir değerlendirme yapılması ve literatürde eksik kalan potansiyel araştırma alanlarının belirlenmesi hedeflenmiştir.

Anahtar Kelimeler: Su altı aracı, denizaltı, serbest su yüzeyi, deniz tabanı, manevra modeli, hidrodinamik katsayı, manevra türevi, hesaplamalı akışkanlar dinamiği, dinamik stabilite, takıntı, sevk

Makale geçmişi: Geliş 18/08/2021 - Kabul 08/12/2021

https://doi.org/10.54926/gdt.983658 


\title{
Assessment of the Maneuvering Characteristics of Underwater Vehicles-II: Effects of Fluid Boundaries
}

\author{
Oğuzhan Kırıkbaş ${ }^{1}$, Ömer Kemal Kınacı ${ }^{2}$, Şakir Bal ${ }^{3}$ \\ 1,2,3 Naval Architecture and Marine Engineering Department, İstanbul Technical University, İstanbul, TÜRKiYE \\ ${ }^{1}$ (corresponding author), kirikbas17@itu.edu.tr, ORCID: 0000-0002-2504-8727 \\ 2 kinacio@itu.edu.tr, 0000-0002-2956-9562 \\ ABSTRACT \\ 3 sbal@itu.edu.tr, 0000-0001-8688-8482
}

Having the motion ability also in the vertical plane, the maneuvering problem of underwater vehicles is a challenging subject that requires mathematical consideration of all degrees of freedom to define the trajectory of the vehicle. Studies in the literature, which address this problem, are mainly focused on the deeply submerged condition of the vehicle. These studies are based on the assumption of infinite fluid field that simplifies the problem. Due to the operational requirements such as communication, positioning, meeting the need for breathing and combustion air, and the survey of the seabed etc. it is inevitable for underwater vehicles to approach fluid boundaries. As a result prediction of vehicle's maneuvering performance under the boundary effects is crucial. This requirement causing further increase in the level of complexity and arise new questions. Issues such as out-of-plane forces resulting from interference effects, effects on propulsion parameters and control surfaces and how all these effects will be represented in the maneuvering model are the most important ones. In order to address all these questions alterations in the maneuvering characteristics of the vehicle due to the presence of boundaries must be examined separately and expressed mathematically. The representation of these mathematically expressed effects in the maneuvering model forms the second phase. In this phase; the use of hydrodynamic coefficients which are functions of governing parameters of boundary flows (Froude number, depth, keel-seabed distance, etc.) in the existing maneuvering models is the widely accepted approach in the literature. The option of deriving a new set of motion equations which takes boundary effects into account is currently in the conceptual stage. Extensive use of underwater vehicles in the proximity of fluid boundaries due to the operational requirements has increased the need for academic studies in this field in recent years. This situation motivates the scholars to investigate the different aspects of the above mentioned topic and led to the gathering of a considerable amount of literature. The scope of this study -which constitutes the second part of the main topic of "assessment of the maneuvering characteristics of underwater vehicles"- is to classify the current literature. The topics to be covered are; changes in the horizontal and vertical planes due to the presence of the free surface and the interactions in between, the interactions between the free surface and appendages, free surface and propulsion system and the effects of the seabed. The efforts regarding the representation of all these effects in the maneuvering models are also discussed. Furthermore, additional difficulties brought by the existence of fluid boundaries in to the numerical and experimental analysis of the problem are mentioned. Thus, it is aimed to provide a general assessment of the subject and identify potential research areas that are not addressed in the literature yet.

Keywords: Underwater vehicle, submarine, free surface, sea bottom, maneuvering model, hydrodynamic coefficient, maneuvering coefficient, computational fluid dynamics, dynamic stability, appendage, propulsion.

Article history: Received 18/08/2021 - Accepted 08/12/2021 
ISSN: 1300-1973, e-ISSN: 2651-530X, Dergi ana sayfası: http://www.gmoshipmar.org/

\section{Terminoloji}

\begin{tabular}{|c|c|c|c|}
\hline ALE & Arbitrary Eulerian-Lagrangian & J & İlerleme katsayısı \\
\hline AFF & Anechoic Flow Facility & $\mathrm{K}$ & Yalpa momenti \\
\hline DARPA & Defence Advanced Research Project Agency & $\mathrm{K}_{\mathrm{T}}$ & İtme katsayısı \\
\hline DES & Dettached Eddy Simulation & $\mathrm{Ka}_{\mathrm{a}}$ & Tork katsayısı \\
\hline DHM & Düzlemsel Hareket Mekanizması & $\mathrm{L}$ & Su altı aracının boyu \\
\hline GPS & Global Positioning System & $\operatorname{lr}$ & $\begin{array}{l}\text { "r" açısal hızı nedeniyle oluşan } \mathrm{N} \\
\text { momentinin moment kolu }\end{array}$ \\
\hline HAD & Hesaplamalı Akışkanlar Dinamiği & $I_{v}$ & $\begin{array}{l}\text { "v" çizgisel hızı nedeniyle oluşan } \mathrm{N} \\
\text { momentinin moment kolu }\end{array}$ \\
\hline ITTC & International Towing Tank Conference & $\mathrm{m}$ & Su altı aracının hidrodinamik kütlesi \\
\hline LES & Large Eddy Simulation & M & Yunuslama momenti \\
\hline MLD & Manoeuvring Limitation Diagram & $\mathrm{M}_{*}$ & Derinliğe bağlı yunuslama momenti \\
\hline OEX & Ocean Explorer & $\mathrm{N}$ & Savrulma momenti \\
\hline RANS & Reynolds Averaged Navier-Stokes & $\mathrm{N}_{\mathrm{v}}^{\prime}$ & $\begin{array}{l}\text { Savrulma momentinin yan öteleme hızına } \\
\text { bağlı değişimi }\end{array}$ \\
\hline RSM & Reynolds Stress Model & $\mathrm{N}_{\mathrm{r}}^{\prime}$ & $\begin{array}{l}\text { Savrulma momentinin savrulma açısal } \\
\text { hızına bağlı değişimi }\end{array}$ \\
\hline SHT & Serbest Hareketli Test & $\mathrm{p}$ & Dinamik Basınç \\
\hline SST & Shear Stress Transport & r & Bağlı eksen takımında açısal savrulma hızı \\
\hline VOF & Volume of Fluid & $\mathrm{t}$ & İtme azalması katsayısı, Zaman \\
\hline$\alpha$ & Hücum açısı & $u$ & Bağ Iı eksen takımında ileri ötelenme hızı \\
\hline$\beta$ & Sürüklenme açısı & $U, V$ & $\mathrm{H} ı \mathrm{z}$ \\
\hline$\rho$ & Yoğunluk & $v$ & Bağlı eksen takımında yanal ötelenme hızı \\
\hline$\lambda$ & Dalga boyu & w & İz katsayısı \\
\hline B & Su altı aracının kalıp genişliği & $W_{a}$ & Model genişliği \\
\hline c & Dip-omurga mesafesi & $W_{c}$ & Çekme tankı genişliği \\
\hline d & Dalma derinliği & $\mathrm{x} / \mathrm{L}$ & Su altı aracı üzerinde boyuna konum \\
\hline $\mathrm{d}_{\text {shaft }}$ & Pervane şaft merkezinin derinliği & $X_{G}$ & Ağırlık merkezinin boyuna konumu \\
\hline $\mathrm{D}$ & Su altı aracının çapı & $x$ & İlerleme yönünde kuvvet \\
\hline$D^{*}$ & Boyutsuz dalma derinliği & $\mathrm{X}_{*}$ & Derinliğe bağlı ileri öteleme kuvveti \\
\hline Derop & Pervane çapı & Y & Yanal öteleme kuvveti \\
\hline$D_{R} *$ & Dümenler için boyutsuz dalma derinliği & $Y_{r}^{\prime}$ & $\begin{array}{l}\text { Yan öteleme kuvvetinin savrulma açısal } \\
\text { hızına bağlı değişimi }\end{array}$ \\
\hline $\mathrm{D}_{\mathrm{s}}^{*}$ & Şaft merkezinin boyutsuz dalma derinliği & $Y_{v}^{\prime}$ & $\begin{array}{l}\text { Yan öteleme kuvvetinin yan öteleme hızına } \\
\text { bağlı değişimi }\end{array}$ \\
\hline e & Boyutsuz deniz tabanı mesafesi & Z & Dalıp-çıkma kuvveti \\
\hline $\mathrm{Fr}$ & Froude Sayısı & $\mathrm{Z}_{*}$ & Derinliğe bağlı dalıp-çıkma kuvveti \\
\hline $\mathrm{F}$ & Serbest su yüzeyi deformasyonları & $\Delta \mathrm{X}_{*}$ & İleri öteleme sapma kuvveti \\
\hline$g$ & Yer çekimi ivmesi & $\Delta \mathrm{Z}_{*}$ & Dalıp-çıkma sapma kuvveti \\
\hline $\mathrm{G}_{\mathrm{h}}$ & Yatay düzlem dinamik stabilite indeksi & $\Delta \mathrm{M}_{*}$ & Yunuslama sapma momenti \\
\hline$h_{\text {kritik }}$ & Kritik dalma derinliği & $\Delta p$ & Basınç gradyeni \\
\hline$h_{R}$ & Dümen derinliği & $\delta_{\text {ro }}$ & Dümen açısı \\
\hline $\mathrm{H}^{*}$ & Boyutsuz kritik dalma derin & & \\
\hline
\end{tabular}




\section{Giriş}

Dalmış cisimlerin hidrodinamik analizleri en genel ve basit hali ile cismin sonsuz bir akışkan alanı içerisinde hareket ettiği varsayımına dayanır. Pratikte akışın incelenen kısmı (kontrol hacmi) akışkanı çevreleyen sınırlara yeterince uzak ise analizlerin bu varsayıma dayanması sonuçların geçerliliği açısından herhangi bir sorun teşkil etmeyecektir. Ancak pratik mühendislik uygulamalarını ilgilendiren dalmış cisimler yalnızca sonsuz akışkan alanı içerisindeki hidrodinamik özellikleri esas alınarak tasarlanamazlar. Örneğin boy ölçeği hedefinin su çekimi ile aynı mertebede olan torpidolar için tasarım aşamasında serbest su yüzeyi etkilerini dikkate almamak torpidonun hedefine yaklaşma safhasındaki hidrodinamik özelliklerinin göz ardı edilmesine ve neticede tasarımın operasyonel ihtiyaçları karşılayamamasına sebep olacaktır.

Karşıladıkları operasyonel intiyaçlar bakımından su altı araçlarının yetenekleri derin dalmış durumdaki ana işlevleri (örneğin denizaltılar için torpido hücumu gerçekleştirme vb.) yerine getirmek için gereken yetenekler ve akışkan sınırlarına yakın sahalardaki ikincil işlevleri (mayın yerleştirme, özel kuvvet harekâtı vb.) yerine getirmek için gereken yetenekler olarak sınıflandırılabilir. Genelde her iki yetenek grubu su altı aracının hidrodinamik açıdan çelişen özelliklere sahip olmasını gerektirir. Örneğin dalmış durumda yüksek manevra kabiliyetine sahip olmaları için düşük dinamik stabiliteli olması istenen askeri maksatlı su altı araçları ikincil işlevlerini yerine getirdikleri çevre şartlarında kolaylıkla stabilite açısından kararsız hale gelebilirler. Ayrıca operasyonel isterler su altı araçlarının artan oranda kıyıya yakın sığ sularda ve dolayısı ile dip ve serbest su yüzeyine yakın kullanımını zorunlu hale getirmekte (Crook, 1994) ve bu durum akışkan alanının sınır etkilerinin hidrodinamik açıdan daha yoğun incelenmesini gerektirmektedir. Bunların yanında denizaltılar birincil işlevlerini yerine getirirken de su sathının periskop/radarla kontrolü, jeneratör çalıştırarak bataryaların şarj edilebilmesi ve solunum havasının ventilasyonu için şnorkel direğini sürme, cevapsız yayınların alınarak iletilecek mesajların gönderilmesi için muhabere direklerinin kullanımı ve GPS üzerinden mevki kalibrasyonu için serbest su yüzeyine yaklaşmaya intiyaç duyarlar. Günümüzde su altı araçlarından giderek artan oranda ikincil işlevleri yerine getirmesi beklendiğinden çelişen isterlerin nihai üründe dengeli bir şekilde temsil edilmesi gereklidir. Dolayısı ile su altı araçlarının serbest su yüzeyine ve deniz dibine yaklaşmaları durumunda manevra özelliklerinin nasıl değişeceğinin incelenmesi giderek daha büyük bir zorunluluk haline gelmektedir.

Önceki çalışmanın (Kırıkbaş vd., 2021) devamı niteliğinde olan bu çalışmanın amacı; serbest su yüzeyi ve deniz tabanı gibi akışkan sınırlarının su altı araçlarının manevra karakteristikleri üzerine etkileri alanındaki literatürü tarayarak; aracın yatay ve düşey düzlemlerde maruz kaldığı kuvvet ve momentlerin, bu düzlemler arası karşılıklı etkileşimlerin ve kontrol yüzeyleri ile sevk sistemi parametrelerinin akışkan sınırları ile karşııklı etkileşimleri özetlemek, bu etkileşimlerin manevra modelinde temsil yöntemlerine değinmek ve bu yolla literatürde daha az çalışılmış başlıkları belirlemektir. Çalışma kapsamında ayrıca akışkan sınırları etkisi altında olmanın manevra probleminin çözümünde kullanılan deneysel ve sayısal yöntemlere getirdiği ilave zorluklara da değinilmiştir.

\section{Serbest Su Yüzeyi, Kritik Derinlik, Su altı Aracının Serbest Su Yüzeyine Etkileri}

Serbest su yüzeyi bir akışkanın yüzeyinde normal gerilmenin sabit ve kayma gerilmesinin sıfır olduğu yüzey bölgesi olarak tanımlanabilir. Serbest su yüzeyi matematiksel olarak denklem (1)'de yer alan serbest su yüzeyi koşulu (dinamik sınır koşulu) ile ifade edilir. Bu denklemde $\frac{D p}{D t}$ basıncın zamana bağlı maddesel türevidir. 


$$
\frac{D p}{D t}=0
$$

Bu ilke momentumun korunumunun bir ifadesidir ve sabit yüzeylerin aksine basınca karşı koyamayan serbest yüzeylerin bir kuvvet dengesi oluşuncaya kadar (yüzeyde basınç atmosfer basıncına eşit oluncaya kadar) deforme olacaklarının bir ifadesidir.

Serbest su yüzeyinin analitik ve sayısal analizi dinamik sınır şartına ilave olarak ayrıca yüzeyin bir materyal yüzeyi gibi davrandığı varsayımına dayanır. Bu varsayım yüzeyi oluşturan akışkan parçacıklarının her zaman yüzeyde kalacağı anlamına gelir ve kinematik sınır şartı olarak adlandırııır. Kinematik sınır şartı denklem (2)'de verilmiştir. Burada $\frac{D F}{D t}$ serbest yüzey deformasyonlarının maddesel türevini alt indis "sy" serbest su yüzeyi anlamına gelmektedir.

$$
\left.\frac{D F(x, z)}{D t}\right|_{s y}=0
$$

Dalmış cisimlerin dalga direnci üzerine yapılan öncü çalışmaların sonuçlarından birisi de dalmış cisim üzerinde serbest su yüzeyinin etkin olmaya başladığı kabul edilen "kritik dalma derinliği" kavramının formülize edilmesidir. Lineer dalga teorisinin kabullerine göre serbest su yüzeyi dalgalarının etkisi dalga boyunun yarısı kadar derinliğe $\left(\mathrm{h}_{\text {kritik }}=0.5 \lambda\right)$ ulaşabilir. Bu kabulden yola çıkarak boyutsuz kritik derinlik cismin boyutlarının ve Froude sayısının bir fonksiyonu olarak denklem (3)'te gösterildiği şekilde elde edilebilir;

$$
H^{*}=\frac{h_{\text {kritik }}}{D}=\frac{\pi L F r^{2}}{D}
$$

Dalga direncinin büyüklüğünün dalma derinliğinin azalan bir fonksiyonu olduğu Gertler (1950), Weinblum vd. (1950) ve Wigley (1953) tarafından fark edilmiş olmasına rağmen analiz edilen cismin geometrik özelliklerinden bağımsız genel geçer bir ölçüt Hoerner (1965) tarafından sunulmuştur. Hoerner boyutsuz dalma derinliğinin 5 'ten büyük olduğu durumlarda serbest su yüzeyi etkisinin ihmal edilebileceğini raporlamıştır. Hoerner (1965)'ten günümüze kadar kritik dalma derinliği konusunda literatürde varılan sonuçlar Tablo 1'de özetlenmiştir.

Tablo 1. Literatürde kullanılan kritik dalma derinliği ifadeleri

\begin{tabular}{|c|l|c|l|}
\cline { 2 - 4 } \multicolumn{1}{c|}{} & \multicolumn{1}{c|}{ Referans } & $\begin{array}{c}\text { Dalma } \\
\text { Derinliği }\end{array}$ & \\
\hline \multirow{2}{*}{1} & Hoerner, 1965 & 5D & Dalga direnci değişimi \\
\cline { 2 - 4 } & Moonesun vd., 2013 & Serbest su yüzeyi deformasyonlarındaki değişim \\
\hline 2 & Nematollahi vd., 2015 & 3D & Serbest su yüzeyi deformasyonlarındaki değişim \\
\hline \multirow{2}{*}{3} & $\begin{array}{l}\text { Jagadeesh ve Murali, } \\
2010\end{array}$ & 2D & $\begin{array}{l}\text { Direnç, kaldırma kuvveti ve yunuslama momentindeki } \\
\text { değişim }\end{array}$ \\
\hline 4 & Zhang ve Zhang, 2014 & L/3 & Direnç ve Serbest su yüzeyi deformasyonlarındaki değişim \\
\hline 5 & Tupper ve Rawson, 2001 & L/2 & Dalga direnci değişimi \\
\hline 6 & Doğrul, 2019 & Frh $\leq 0.7$ & Direnç ve Serbest su yüzeyi deformasyonlarındaki değişim \\
\hline
\end{tabular}

Kritik dalma derinliğinin belirlenmesinde düşey düzlem kuvvet ve momentlerinin dirençten daha belirleyici olduğu Conway vd. (2018) tarafından ortaya konmuştur. Kritik dalma derinliğinin altındaki 
derinliklerde hareket eden bir cisim yüzeyde kendi hızı ile eşit hızla hareket eden bir dalga sistemi oluşturur. Bu yüzey dalgası sistemi serbest su yüzeyinin cismin dinamik basınç alanı nedeniyle deformasyonunun bir sonucudur (Dawson, 2014). Bu durumun bir istisnası, su altı aracının derin dalmış durumda farklı yoğunluklara sahip iki su tabakasını ayıran yüzeye yakın hareket etmesidir. Çok fazlı akış olarak sınıflandırılabilecek bu durumda da su altı aracı dalga direncine maruz kalır (Tupper ve Rawson, 2001, p. 387).

Bu dalga sistemlerinin Froude sayısına bağlı yapıcı ve yıkıcı girişimleri cisme etkiyen kuvvet ve momentlerde değişime (veya yeni kuvvet ve momentlerin oluşumuna) dolayısı ile manevra karakteristiklerinin değişmesine neden olur. Öte yandan yüzey dalga sistemini oluşturan bileşenlerin dalga boyu 0.50 'den büyük Froude sayıları için birbirleri ile etkileşime giremeyecek kadar büyük olacaktır. Bu durum bahse konu Froude sayısına karşılık gelen hız değerinin aşılması durumunda su altı aracına yüzey dalga sistemi nedeniyle etkiyen kuvvet ve momentlerin sabit kalacağı anlamına gelir (Dawson, 2014).

Serbest su yüzeyi etkisi ile kuvvet ve momentler ve dolayısı ile manevra karakteristiklerindeki tüm değişimler yukarıda bahsedilen dalga etkileşimleri ile açıklanabilir. Ancak bu etkileşimlerden bir tanesi diğerlerine göre baskın karakterdedir (Amiri vd., 2018a). Serbest su yüzeyini yaran geometriler için başkıç dalgası arasındaki etkileşimin cismin direnç karakteristiği üzerinde baskın etkisi olduğu bilinmektedir. Amiri vd. (2018a) su altı araçları için benzer bir etkiye baş-kıç omuzluk dalga etkileşimlerinin sebep olduğunu göstermiş, bu farklılığın sebebini de klasik su altı aracı geometrileri için kıç omuzluğun satıha cismin kıç kısmından daha yakın olması ile açıklamıştır.

\section{Dalmış Cismin Maruz Kaldığı Kuvvetler}

Serbest su yüzeyinin varlığı nedeniyle cismin manevra karakteristiklerinin nasıl etkilendiği ancak cisme etkiyen kuvvetlerdeki değişimin analizi ile mümkündür. Saout (2003) dalmış bir cisme etkiyen kuvvetleri Şekil 1'de gösterildiği gibi sınıflandırmıştır.

Ağırlık ve sephiye dengesinin sağlanmasının cisimlerin dalmış durumda kalabilmelerinin ön şartıdır. Bu iki kuvvetin bileşke etkisinin sıfır olduğu düşünüldüğünde, yeterince derine dalmış ve ana ekseni akış doğrultusunda konumlandırılmış bir cismin, herhangi bir sınır etkisinin bulunmadığı bu simetri durumda Şekil 1'de gösterilen kuvvetlerden yalnızca direnç (viskoz) kuvvetine maruz kaldığı söylenebilir. Cisim bu durumdayken sakin su yüzeyine (Froude Krylov ve kırınım kuvvetleri mevcut değil) yaklaşması halinde etrafındaki simetrik akışkan sahası serbest su yüzeyinin varlığı sebebiyle bozulacak, yüzeye yaklaşan cisim ile yüzey arasında kalan akışkan hacmi cisim ile deniz tabanı arasında kalana kıyasla azalacaktır.

Akışkan hacminin azaldığı tarafta akışın hızının artması beklenir. Bernoulli Illkesini kullanarak söz konusu bu hız değişiminin cismin etrafındaki dinamik basınç alanının değişimi ile doğru orantılı olduğu Denklem (4) ve (5)'te olduğu gibi gösterilebilir;

$$
\Delta p=\frac{\rho}{2} \cdot\left[(V+\delta V)^{2}-V^{2}\right]
$$

ve doğrusallaştırma ile,

$$
\Delta p \cong \rho V \delta V
$$


Burada $\Delta p$ basınç gradyenini $\delta V$ ise akışkan hızındaki değişimi ifade etmektedir. Şekil 2'de gösterildiği gibi değişen bu basınç alanı ile etkileşime giren serbest su yüzeyi deforme olmaya başlar, yüzeyde cisme göre durağan ve cismin boyutlarının, hızının ve derinliğinin bir fonksiyonu olan yerçekimsel dalga sistemi oluşur. Karşılığında bu dalga sistemi, kendisini oluşturan basınç alanını etkileyerek daha ileri seviyede değişmesine ve böylece cismin ilave yayınım (radiation) kuvvetlerine (ve momentlere) maruz kalarak manevra karakteristiklerinin etkilenmesine (Griffin, 2002) sebep olur.

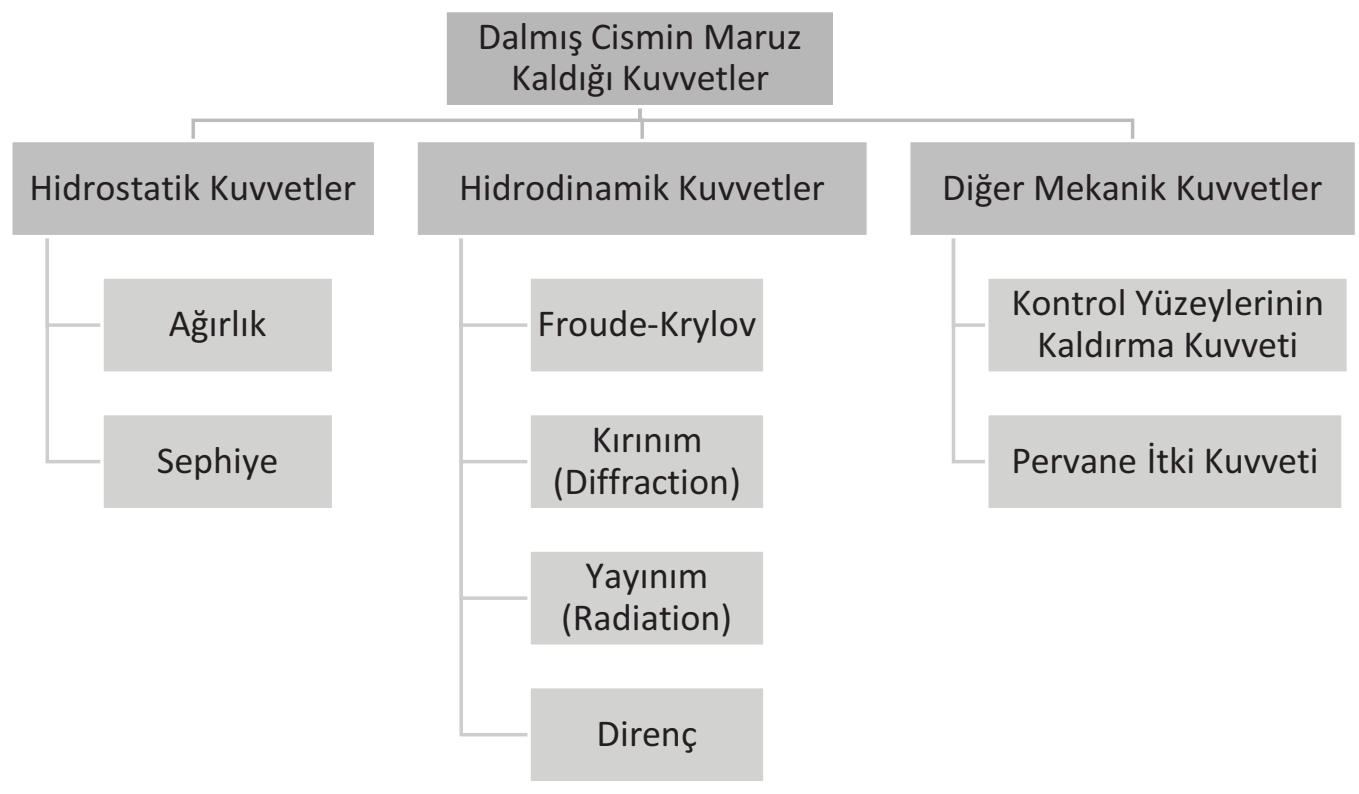

Şekil 1. Dalmış cismin maruz kaldığı kuvvetler

Literatürde dalmış cismin manevra karakteristiklerindeki değişimin analizi; öncelikle yayınım (radiation) kuvvetlerinin eksenel ve daha sonra düşey doğrultudaki bileşeni ve bu bileşenin neden olduğu momentin incelenmesiyle başlamıştır.

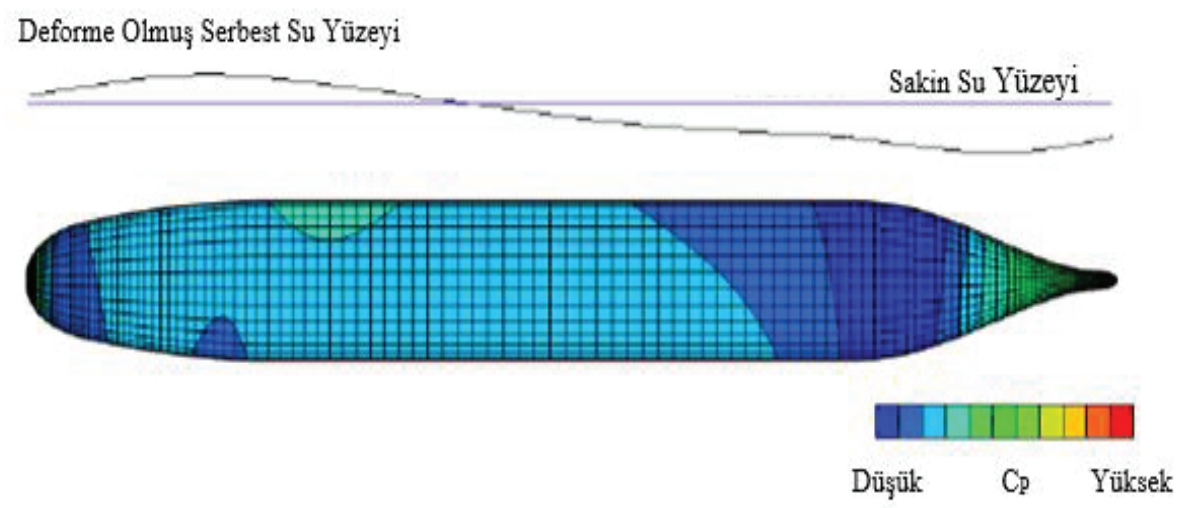

Şekil 2. Etkileşim sebebiyle deforme olmuş serbest su yüzeyi ve değişen dinamik basınç (Dawson, 2014)

Bu noktaya kadar cismin ana ekseni halen akış yönü doğrultusunda konumlandırılmış durumdadır. Serbest su yüzeyine yakınlığın cismin oryantasyonundaki değişimler, mekanik kuvvetler ve cismin zamana bağlı hareketleri ile karşılıklı etkileşimi daha sonraki süreçte araştırmacılar tarafından incelenmiştir. Söz konusu incelemelerin sonuçlarına bu çalışmanın 6. bölümünden itibaren değinilmiştir. 


\section{Dalga Direncinin Analitik ve Deneysel Yöntemlerle İncelenmesi: Illk Çalışmalar}

Akışkan sınırlarının yukarıda sayılan sebeplerle probleme dâhil edilerek dalmış cismin yayınım (radiation) kuvvetlerine maruz kalmasının hidrodinamik açıdan literatürde en fazla incelenen bileşeni dalga direnci olarak bilinir. Araştırmacılar tarafından bu bileşenin hesaplanması için gösterilen gayretlerin geçmişi geçen yüzyılın başlarına kadar dayanmaktadır. Havelock'un geliştirdiği analitik yöntem kendisinden sonraki çalışmalar için bir ölçüt teşkil etmiştir.

Analitik yöntemlerin o günkü sınırlarına ulaşmış ve sayısal yöntemlerin henüz olgunlaşmamış olması araştırmaların bundan sonraki yönünü deneysel çalışmalara çevirmiştir. Gertler (1950) gerçekleştirdiği deneylerde çeşitli geometrik parametrelerin değişiminin dalmış cismin direnci üzerine etkisini ölçmüştür. Bu deney serisi direnç açısından en uygun geometrik parametreleri belirlemeyi hedeflemektedir. Bu çalışma kapsamında yazar serbest su yüzeyine yakın cisimlerin prizmatik katsayılarındaki değişimin dirence olan etkisini de incelemiştir. Yazar incelenen deney senaryolarına ait sonuçları kullanarak bir kanıya varmamıştır. Havelock'un analitik çalışmalarının devamı ve elde ettiği sonuçların deneysel doğrulaması Weinblum vd. (1950) tarafından gerçekleştirilmiştir.

Bu deney serisinde Havelock tarafından analitik olarak incelenmiş geometriler kullanılmış; dalma derinliği, hız ve geometrik parametrelerin direnç üzerine etkileri ölçülerek sonuçlar analitik yöntemden elde edilen değerlerle kıyaslanmıştır. Her iki yöntem de dalmış cisimler için toplam direnç eğrisinin suüstü gemilerininkine benzer karakteristik özellikler (hızın fonksiyonu olarak direnç eğrisi üzerinde tepe ve çukurlar) sergilediğini göstermiş, Weinblum Havelock'un analitik yönteminin niteliksel anlamda geometrik parametreler ve hız değişiminin dirence etkilerini analiz etmekte yeterli bir yöntem olduğu sonucuna varmıştır.

Serbest su yüzeyine yakın seyreden dalmış cisimlerin hidrodinamiği alanındaki literatüre sonraki başlıca katkı 5:1 eksen oranına sahip uzatılmış küremsi cisimlerin direnç bileşenlerinin ölçülmesi/hesaplanması için Farell ve Guven (1973) ve Farell, (1973) tarafından yapılmıştır. Farell 5:1 eksen oranlı küremsi cisim etrafındaki akışı Neumann-Kelvin yöntemi ve cismin yüzeyine uyguladığı kaynak (source) dağııımını kullanarak çözmüş ve sonuçları Havelock'un elde ettiği sonuçlar ile kıyaslamıştır. Farell, Havelock'un yaklaşımının tekillik dağılımın cismin simetri ekseninde olması nedeniyle cismin üzerindeki sınır koşulunu tam olarak sağlayamadığını ve dolayısı ile hatalı sonuçlara sebep olduğu sonucuna varmıştır.

Küremsi cisimler için Neumann-Kelvin probleminin alternatif bir çözümü Doctors ve Beck (1987) tarafından yapılmıştır. Yazarlar bu çalışmada Farell'in kullandığı cismin yüzeyinin kaynak dağııımı ile temsil edilmesi yönteminden farklı olarak cismin yüzeyini temsil etmek için Hess ve Smith, (1964) tarafından önerilen panel yöntemini kullanmışlar ve hesaplama sonuçlarının (düşük Froude sayıları hariç) Farell ile paralellik sergilediğini raporlamışlardır.

\section{Dalga Direncinin Sayısal Yöntemlerle İncelenmesi}

Günümüzde; diğer mühendislik akışlarına benzer şekilde su altı araçlarının maruz kaldığı iki fazlı/duvarla sınırlandııımış (wall-bounded) akışların incelenmesi için çoğunlukla sayısal analizler kullanılmaktadır. Dolayısı ile bu çalışmanın bütünlüğü açısından, sayısal yöntemlerin su altı aracının dalga direnci problemine uygulandığı yakın tarihli çalışmaların özetlenmesi gereklidir. (Uslu ve Bal, 2008) Dawson'ın (1977) geliştirdiği yöntemi farklı eksen oranlarına sahip elipsoit geometrilerine uygulamışlardır. Bu yöntem cismin ve serbest yüzeyin Rankine kaynak terimleri ile temsil edilmesine dayanmaktadır. Yazarlar değişik Froude sayıları için bu geometrilere ait toplam direnç katsayısı 
sonuçları ile referans çalışma (Farell, 1973) sonuçları arasındaki uyumun tatmin edici seviyede olduğunu sonucuna varmışlardır.

(Guanghua, 2013) geliştirdiği BEM tabanlı yöntemi 5:1 eksen oranlı uzatılmış küremsi cismin dalga direncini hesaplamak için kullanmışlardır. $D^{*}=0.8$ için farklı Froude sayılarına ait hesaplama sonuçlarını doğrulamak için (Doctors \& Beck, 1987) çalışmasının sonuçlarını referans olarak kullanmışlardır. Her iki çalışma arasında sonuçların tutarlıı̆ının tatmin edici olduğu ifade edilmiştir.

(Wilson-Haffenden vd., 2010) ise çekme tankı verileri ile doğruladıkları sayısal bir çalışma icra etmişlerdir. Bu çalışma kapsamında yazarlar farklı Froude sayılarında ve derinliklerde DARPA Suboff AFF-1 konfigürasyonu için toplan direnç katsayısı $\left(C_{D}\right)$ sonuçlarını kıyaslamışlardır. Sonuç olarak dalga direncinin etkisi nedeniyle toplam direnç katsayısındaki artışın (Hoerner, 1965) sonuçları ile tutarlılık sergilediğini belirlemişlerdir. Buna göre $\mathrm{Fr}=0.27 \sim 0.35$ aralığında toplam direnç katsayının azami değerine ulaştı̆̆ı sonucunu elde eden yazarlar (Hoerner, 1965)'in azami direnç değişiminin 0.31'e karşılık gelen hızlarda gerçekleştiğine yönelik bulgusunu desteklemişlerdir. Yazarlar ayrıca bu sonuçlardan yola çıkarak $\mathrm{Fr}<0.35$ ve $D^{*}>2.2$ koşullarında dalga yapma direncinin ihmal edilebileceğini belirtmişlerdir.

(Doğrul, 2019) gerçekleştirdiği sayısal çalışmasında DARPA Suboff AFF-1 ve AFF-8 konfigürasyonlarını kullanmıştır. Yazar derinliğin ve takıntıların direnç bileşenlerine ve serbest yüzey deformasyonlarına etkisini incelemiştir. Buna göre derinliğe bağlı Froude sayısının $\left(\mathrm{Fr}_{h}\right)$ 0.7'den küçük olması durumunda incelenen geometrilerin tamamen dalmış bir cisim davranışı sergilediğini tespit etmiştir. Yazar ayrıca $3.051 \mathrm{~m} / \mathrm{s}$ hız değerinin her iki geometrik konfigürasyon için de bir eşik değer olduğunu belirlemiştir. Bu hızdan daha büyük hızlarda dalga direncinin çalışmaya konu olan her bir derinlik değeri için hız artışından bağımsız hale gelerek sabit kaldığını göstermiştir.

\section{Manevra Karakteristiklerine Etkiler: Düşey Düzlemdeki Etkiler}

Serbest su yüzeyinin varlığının su altı araçlarının kontrolü ve dolayısı ile manevrası üzerine etkileri ancak serbest su yüzeyiyle etkileşim sebebiyle oluşan diğer kuvvet bileşenlerinin ve bu bileşenlerin yarattığı momentlerin de incelenmesi ile tam olarak anlaşılabilir. Cisim; hissettiği eksenel yönlü kuvvetin yanında, akışın düşey yönde simetrisinin serbest su yüzeyinin varlığı ile bozulması sonucunda düşey yönde de bir kuvvet ve yunuslama momentine maruz kalır. Simetrinin ortadan kalkması yüzeye yaklaşan cisim ile yüzey arasında kalan akışkan hacminin cisim ile deniz tabanı arasında kalana göre daha az olmasına bu da serbest su yüzeyinin altındaki akışkanın hızlanarak basıncın düşmesine (Bernoulli Prensibi) yol açar. Basıncın düşmesi cismin etrafındaki basınç alanının düşey yönlü simetrisinin bozulmasına ve bozulan basınç alanının integrasyonu ise cisme Şekil 3'te gösterildiği gibi düşey yönlü bir kuvvet ve moment etkimesine neden olur.

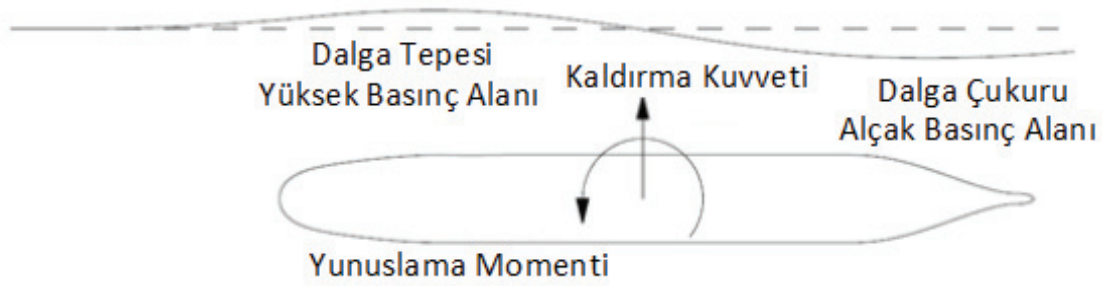

Şekil 3. Serbest su yüzeyiyle etkileşim nedeniyle düşey düzlemde kuvvet/momentler (Dawson, 2014) 
Bu kuvvet ve momentin etkileri su altı aracının Froude sayısına bağlı olarak dalmasına veya satıha daha da yaklaşarak serbest su yüzeyini yarmasına ve her durumda kontrol sisteminin aşırı kullanımına yol açar. Böylece su altı aracının görsel olarak tespit edilmesi, icra ettiği operasyonun (şnorkel, muhabere vb.) aksaması veya oluşan yunuslama momenti sebebiyle pervanenin satıha yaklaşarak sevk veriminin azalması ihtimalini artırırlar. Wigley (1953)'in çalışması; Havelock tarafından geliştirilen yöntemin düşey yönlü kuvvetin ve yunuslama momentinin hesaplanması için uyarlanması suretiyle bu alana öncülük etmiştir.

Wigley'in çalışmasının en önemli sonucu cisim tarafından hissedilen düşey yönlü kuvvetin (kaldırma kuvveti) Froude sayısına bağıı olarak yön değiştirdiğinin tespit edilmesidir. Düşük Froude sayılarında kuvvet yukarı yönlüdür. Bu hızlarda araç serbest su yüzeyine doğru çekilir. Froude sayısının (hızın) artmasıyla kuvvetin büyüklüğü giderek azalır. Kritik bir hızda kuvvet yön değiştirerek aşağı yönlü (deniz tabanına doğru) hale gelir. Başka bir deyişle su altı aracını dibe doğru çekecek şekilde etki etmeye başlar. Wigley ayrıca cisme serbest su yüzeyinin varlığı nedeniyle etkiyen kaldırma kuvveti ve yunuslama momentinin Froude sayısına bağlı değişimini de incelemiştir. Bu çalışmanın sonuçları Tablo 2'de özetlenmiştir.

Tablo 2. Serbest su yüzeyine yaklaşan su altı aracının maruz kaldığı kaldırma kuvveti ve yunuslama momentinin Froude sayısına bağlı değişimi.

\begin{tabular}{|l|c|c|}
\cline { 2 - 3 } \multicolumn{1}{c|}{} & $\begin{array}{c}\text { Düşük } \\
(0.15<\mathrm{Fr}<0.55)\end{array}$ & $\begin{array}{c}\text { Yüksek } \\
(\mathrm{Fr}>0.55)\end{array}$ \\
\hline Z Kuvveti Yönü & Yukarı & Aşağı \\
\hline M Moment Yönü & Baş Aşağı & Baş Aşağı \\
\hline
\end{tabular}

Hesaplamalarını direnç analizinin ötesine genişleten bir diğer çalışma ise Doctors ve Beck'in yukarıda bahsedilen çalışmasıdır. Panel yöntemler kullanılarak elde edilen Neumann-Kelvin probleminin sonuçlarından kaldırma kuvveti ve yunuslama momenti katsayılarını da elde etmiş ve sonuçları Wigley (1953) ile kıyaslamışlardır. Her iki çalışmanın sonuçları kaldırma kuvveti ve yunuslama momentinin Froude sayısına bağı ı değişimi açısından tutarlılık sergilemektedir. Her iki çalışmada da dalga direncinin derinliğe bağı değişimine benzer şekilde kaldırma kuvvetinin ve trim momentinin büyüklüğünün derinliğin azalan bir fonksiyonu olduğu sonucuna varılmıştır.

Literatürde bundan sonraki çalışmalar düşey düzlem büyüklüklerin hesaplama yöntemleri, bu yöntemlerin iyileştirilmesi ve bu büyüklüklerin aracın kinematik parametrelerine göre değişimini incelemeyi amaçlasalar da bu değişimin sebepleri üzerinde yeteri kadar durulmamıştır. Aracın hızına bağlı serbest su yüzeyi deformasyonlarının şeklinin bu kuvvet ve momentlerin yönü ve şiddeti üzerindeki belirleyici etkisi birçok araştırmacı tarafından vurgulanmış (Dawson, 2014; Griffin, 2002) ancak bu olguların asıl sebepleri yakın zamana kadar araştırma konusu olmamıştır.

Sayısal yöntemlerin gelişmesi geometrik parametrelerin etkilerinin sonraki süreçte daha kapsamlı analiz edilebilmesi imkânını sağlamıştır. Crook (1994) boyutsal parametrelerin (boy ve çap), Doctors ve Beck'in geliştirdiği yöntemi jenerik bir nükleer saldırı sınıfı denizaltı (SNN) geometrisi olan DARPA Suboff'a uygulayarak dalga direnci, kaldırma kuvveti ve yunuslama momenti üzerinde etkilerini analiz etmiştir. Her üç büyüklüğün hız ve derinliğe bağlı değişiminin önceki çalışmaların sonuçları ile tutarlı olmasından yola çıkan yazar, kaldırma kuvvetinin hızın ve derinliğin azalan bir fonksiyonu olması olgusundan düşük süratlerde satıha yakın bir denizaltının kontrolünün daha zor olacağını ve bu hızlarda gerçekleşen pozitif (baş aşağı) yönlü yunuslama momenti nedeniyle de öncelikle denizaltının kıç 
bölgesinin ve pervanenin serbest su yüzeyini yaracağını ifade etmiştir. Crook denizaltının kontrol edilebilirliği ve gizliliğini olumsuz yönde etkileyecek bu iki olgunun önüne geçebilmek için satıha yakın seyrederken mümkün olan en yüksek süratin kullanılması gerektiğini belirtmiştir.

Kontrol edilebilirlik vb. nedenlerle satıha yakın yüksek süratle seyretmek denizaltıdan akışkana daha fazla kinetik enerji aktarılması neticesinde yaratılan yüzey dalgalarının genliğinin artması ve dalgaların diğer yüzer platformlar ile uydulardan tespit edilebilmesi anlamına gelecektir. Denizaltının serbest su yüzeyinde yarattığı bu deformasyonların tespit edilmesi ise; konumunun, rotasının, hızının ve boyutlarının belirlenebilmesine imkân sağlar. Bu nedenle denizaltılar serbest su yüzeyine yakın oldukları durumlarda da mümkün olan en düşük süratle kontrol edilebilecek manevra özelliklerine sahip olmaları hedeflenmelidir (Tolliver, 1996).

Tamamıyla potansiyel teoriye (panel yöntemler) dayalı önceki çalışmalarda serbest su yüzeyinin dalmış cismin hareketini nasıl etkilediğine ilişkin bir takım niteliksel sonuçlara ulaşılmış olmasına rağmen bir manevra modelinde cismin doğrusal veya rotasyonel hareketi nedeniyle maruz kaldığı tüm kuvvet ve momentleri temsil eden manevra katsayılarının eksiksiz hesaplanması viskoz etkiler göz ardı edildiği için yapılamamışır. Sayısal analiz altyapısının belirli bir düzeye ulaşması viskoz etkilerin de (en azından cismin etrafında akışın viskoz olduğu düşünülen bölge için) hesaplamalara dâhil edilmesine imkân tanımıştır. Griffin (2002) çalışmasında değişik denizaltı geometrilerinin etrafındaki akışı viskoz ve ideal akış bölgelerine ayırmış ve her bir bölge için akışı yöneten denklemleri ayrı ayrı çözmüştür. Griffin'in yönteminin öne çıkan yönü birbirinden farklı kabullere dayalı denklemlerle yönetilen bu iki akış sahası arasında sayısal algoritmanın iletişimini bir kesişim bölgesi vasıtasıyla yapmasıdır. Griffin böylece panel yöntemler ile RANS denklemlerine dayalı viskoz hesaplamaların karşılıklı etkileşiminden seçtiği geometriler için düşey düzlemdeki manevra katsayılarının eksiksiz bir tahminini yapabilmiştir.

Tahara ve Stern, 1994 daha önce suüstü gemileri için geliştirilen RANSE tabanlı bir yöntemi kullanarak sınır tabakanın etkilerini de hesaplara dâhil etmişlerdir. Griffin'in çalışması ise viskoz etkilerin ele alınış biçimi açısından literatürde önemli bir noktada durmaktadır.

Viskoz etkilerin sayısal analizlere dahil edilmesinin güç taraflarından birisi kapalı denklem sisteminin nasıl elde edileceğidir. Araştırmacılar bu problemi ele almak için öncelikle RANS yöntemini kullanmışlardır. Bu yöntem akışı kontrol eden denklemlere Reynolds gerilme terimlerinin eklenmesine neden olur. Bu gerilme terimleri ile birlikte denklem sistemini kapalı hale getirmek için bir çok türbülans modeli geliştirilmiştir. Su altı araçlarının etrafında gelişen karmaşık akış sahalarının akışın fiziğine uygun bir şekilde analizlere yansıtılabilmesi için türbülansın etkilerinin çözülen problem özelinde doğru bir şekilde modellenmesi gereklidir. Literatürde viskoz yöntemlerin kullanılmaya başlanması, araştırmacıların gayretlerinin türbülans modellerinin uygulanması, karşılaştırılması ve iyileştirilmesi gibi konulara yönelmesine sebep olmuştur. Jagadeesh ve Murali (2010) Afterbody-1 geometrisi üzerindeki akışı kontrol hacminin tamamında RANS denklemleri ve farklı türbülans modelleri kullanarak çözmüş ve derinliğin ve seçilen türbülans modelinin düşey düzlem parametreleri (direnç, kaldırma kuvveti ve yunuslama momenti) üzerine olan etkisini analiz etmişlerdir. Bu analizler sonrasında yazarlar şu sonuçlara ulaşmışlardır.

- Direnç, kaldırma kuvveti ve Yunuslama momenti derinliğin azalan birer fonksiyonudurlar.

- Derinliğin etkisi direnç için hücum açısı arttıkça azalır, kaldırma kuvveti ve yunuslama momenti için ise sabit kalır. 
Yazarlar ayrıca her üç büyüklük için de $D^{*}=2$ 'den daha büyük derinlikte gözlemlenen derinliğe bağı değişimin ihmal edilebilir seviyede olduğunu belirtmişlerdir. Burada $D^{*}$ boyutsuz dalma derinliği olup Denklem (6)'da hesaplama yöntemi verilmiştir. Denklem (6)'da yer alan ifadede " $d$ " su altı aracının derinliğini " $D$ " ise çapını temsil etmektedir.

$$
D^{*}=\frac{d}{D}
$$

Benzer çalışmalar daha sonra Polis vd. (2013b, 2013a) tarafından DARPA Suboff AFF-1 geometrisinin hücum açısının $0^{\circ}$ derinliğin $D^{*}=1.8^{\sim} 2.8$ olduğu durum için yapılmıştır. Birinci çalışmanın incelenen kuvvet ve momentlerdeki değişim verisi kullanılarak ikinci çalışma derinliğin de fonksiyonu olan hidrodinamik katsayıları hesaplamayı hedeflemiştir.

Su altı araçlarının emniyetli seyir yapabilmesi için serbest su yüzeyiyle etkileşim sebebiyle oluşan ve aracın düşey düzlem stabilitesi üzerinde olumsuz etkisi olan kaldırma kuvvetini ve yunuslama momentini karşılayabilecek şekilde tasarlanmaları gerekir. Başka bir deyişle ufki kontrol sisteminin kapasitesi aracın hızına ve derinliğine bağlı olarak maruz kalabileceği düşey düzlem etkilerini karşılayarak Şekil 4'te gösterildiği gibi araç üzerindeki kuvvet dengesini koruyacak şekilde seçilmelidir.

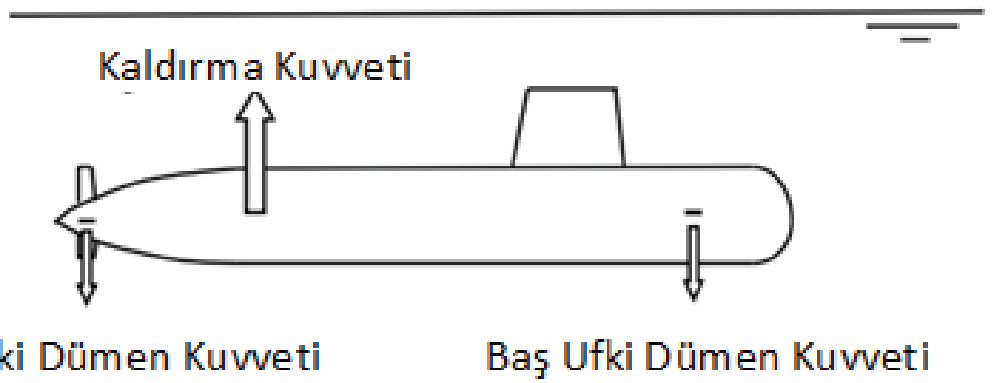

\section{Kıç Ufki Dümen Kuvveti Baş Ufki Dümen Kuvveti}

Şekil 4. Düşey düzlemde su altı aracının üzerindeki kuvvet dengesi (Renilson, 2015)

Yukarıdaki iki çalışmanın sonuçlarını kullanarak Renilson vd. (2014) DARPA Suboff AFF-1 geometrisinin $D^{*}=1.8^{\sim} 2.8$ derinlik ve $\mathrm{Fr}=0.38^{\sim} 0.48 \mathrm{hız}$ aralığında maruz kalacağı kaldırma kuvveti ve yunuslama momentini karşılayabilmek için gerekli ufki dümen (baş ve kıç) açılarını baş ufki dümenin iki farklı yerleşim alternatifi için RANS yöntemleri kullanarak hesaplamışlardır.

Buna göre kaldırma kuvvetinin büyüklüğü gibi etki merkezinin de Froude sayısının bir fonksiyonu olduğu Şekil 5'ten görülebilmektedir. Bu durum yunuslama momentindeki Froude sayısına bağlı değişimin de sebebidir. Froude sayısı arttıkça basınç merkezi su altı aracının kıç kısmına doğru kaymaktadır (Şekil 5). Froude sayısının 0.42 0.44 değerleri arasında bu kayma hesaplamaya konu tüm derinlikler için basınç merkezinin su altı aracının dışında kalmasına sebep olur. Yazarlar bunun nedeninin aracın hareketi nedeniyle serbest su yüzeyinde oluşan dalgalar olduğunu varsaymışlardır.

Şekil 5 incelendiğinde yüksek Froude sayıları için kaldırma kuvvetinin merkezinin aracın üzerinde olmadığı görülebilir $(x / L<-0.5)$. Bu durum Şekil 6 'dan da görülebileceği üzere baş ufki dümenlerin derinliğe bağıı olarak değişen kritik bir Froude sayısından küçük hızlarda aşağı, büyük hızlarda ise yukarı yönlü hareket ettirilmesi ihtiyacını doğurur. Ayrıca yine Şekil 6'den anlaşılacağı gibi moment kolunun uzun olması nedeniyle aracın baş tarafına yerleştirilen baş ufki dümenler kuvvet dengesini sağlayarak aracı sabit derinlikte tutmak için yelkende yer alanlara göre daha küçük dümen açılarına intiyaç duyacaktır. 


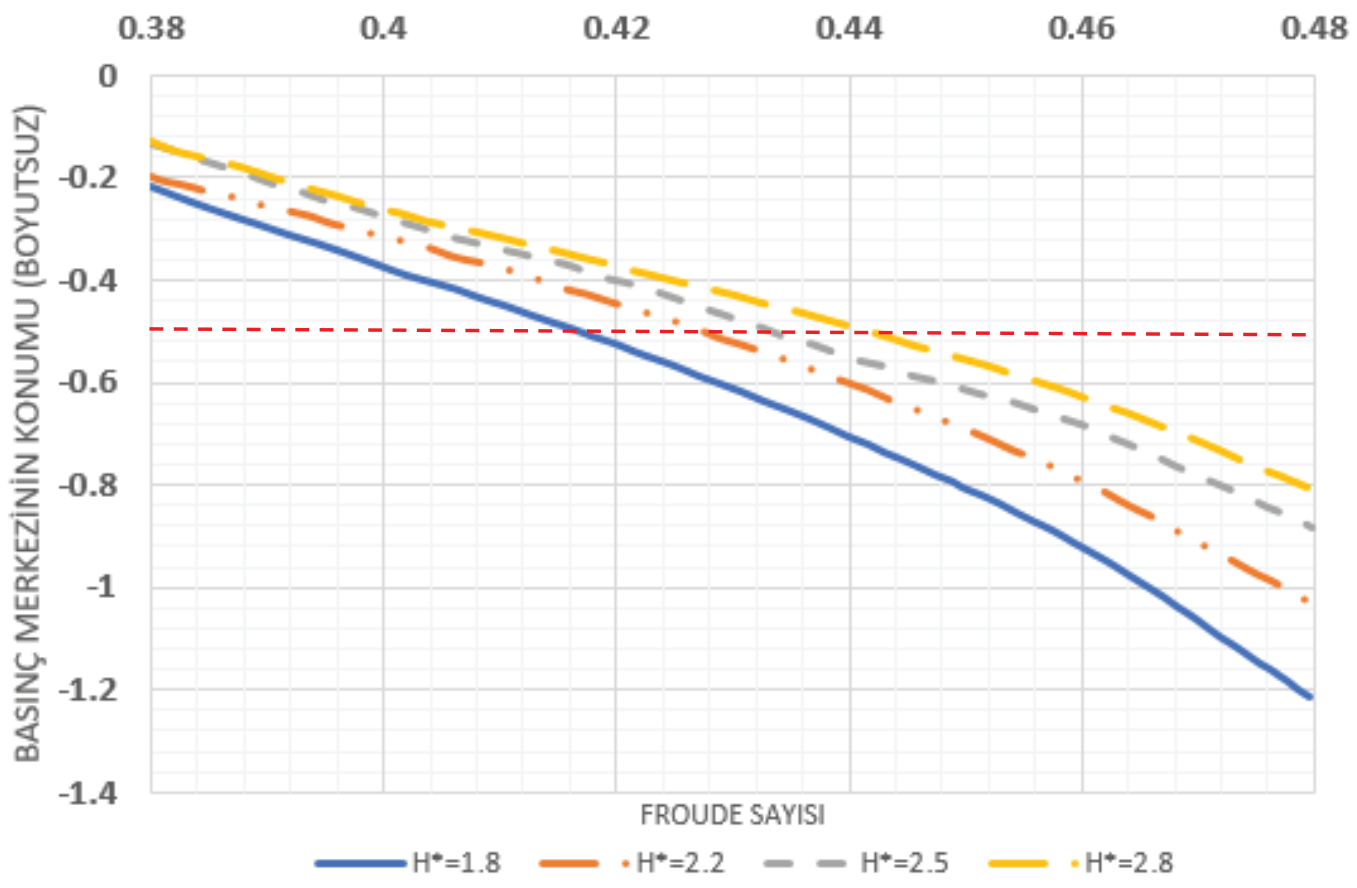

Şekil 5. Farklı derinlikler için dinamik basınç merkezinin boyuna konumu - Froude sayısı değişimi (Renilson vd., 2014)

Düşey düzlem büyüklükleri üzerinde serbest su yüzeyinin baskın etkisi potansiyel teoriye dayalı panel yöntemlerin günümüzde de viskoz yöntemlere alternatif olarak kullanılmaya devam edilmesini sağlamaktadır. Yakın geçmişte Dawson (2014) ve Gourlay ve Dawson (2015) tarafından çeşitli geometriler kullanılarak bu geometrilerin direnç, kaldırma kuvveti ve yunuslama momentini hesaplamayı hedefleyen çalışmalar örnek olarak gösterilebilir. Ancak bu alanda yapılan çalışmaların birçoğu viskoz yöntemlerin etkinliğini artırmayı hedefleyen çalışmalardır.

Örneğin Salari ve Rava (2017) Afterbody-1 geometrisi için direnç ve kaldırma kuvveti katsayılarını k- $\omega$ SST türbülans modeline ilave olarak laminer-türbülans geçişini yakalayan iki transport denklemi ile birlikte çözmüş ve sonuçları Jagadeesh vd. (2009) tarafından gerçekleştirilen deney sonuçları ile

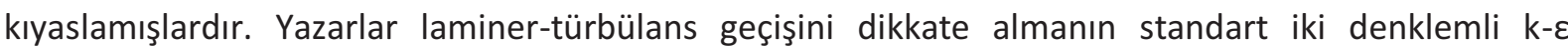
türbülans modeline göre deney datasına daha yakın sonuç verdiğini göstermişlerdir.

Amiri vd. (2018a) düşey düzlemde serbest su yüzeyinin varlığı nedeniyle meydana gelen değişimlerin sebeplerine ayrıntılı olarak değinmişlerdir. Buna göre yazarlar su altı araçlarının serbest su yüzeyi ile etkileşim sebebiyle düşey düzlemde maruz kaldığı kuvvet ve momentlerin aracın Kelvin izini oluşturan belirli dalga sistemlerinin etkileşiminden kaynaklandığını tespit etmişlerdir.

Baş dalgasının çukurunun kıç omuzluktaki düşük basınç alanı ile etkileşiminin düşey düzlem büyüklükleri üzerinde anılan belirleyici etkiyi oluşturduğunu ifade eden yazarlar DARPA Suboff AFF-1 geometrisinin $\mathrm{Fr}=0.205^{\sim}$ 0.512'ye karşılık gelen hızlarında ve aracın incelenen derinliklerden serbest su yüzeyine en yakın derinliği için $\left(D^{*}=1.1\right)$ maruz kaldığı kuvvet ve momentlerdeki değişimi şu şekilde özetlemişlerdir;

- $h=3.3 \mathrm{D}$ dalma derinliğinde baş dalgasına ait dalga çukurunun, 0.269 ve 0.411 sayılarına karşılık gelen hızlarda su altı aracının kıç tarafında büyük bir alanı kapsaması ve dalga çukurunun yarattığı düşük basınç alanının kıç omuzluk düşük basınç alanı örtüşmesi Şekil 7'den de 
görülebileceği üzere bu noktalarda tepe noktasına ulaşan yukarı yönlü (pozitif) bir kaldırma kuvvetinin oluşmasına neden olmaktadır.

- Kıç tarafta oluşan yukarı yönlü kaldırma kuvveti, 0.3'ten küçük Froude sayılarında baş tarafta oluşan aynı yönlü kaldırma kuvvetinden daha baskın olduğundan yunuslama momentinin Şekil 8'de görüldüğü gibi baş aşağı (pozitif) yönlü olmasına neden olmaktadır.

- 0.30-0.35 aralığındaki Froude sayılarında baş dalga çukurunun aracın baş kısmına denk gelmesi (dalga sistemleri arasında etkileşimin olmaması) baş tarafta yukarı yönlü bir kaldırma kuvveti oluşturarak yunuslama momentinin de yön değiştirmesine neden olmaktadır.

UFKI DÜMENLERIN BAŞ KONFIGÜRASYONU

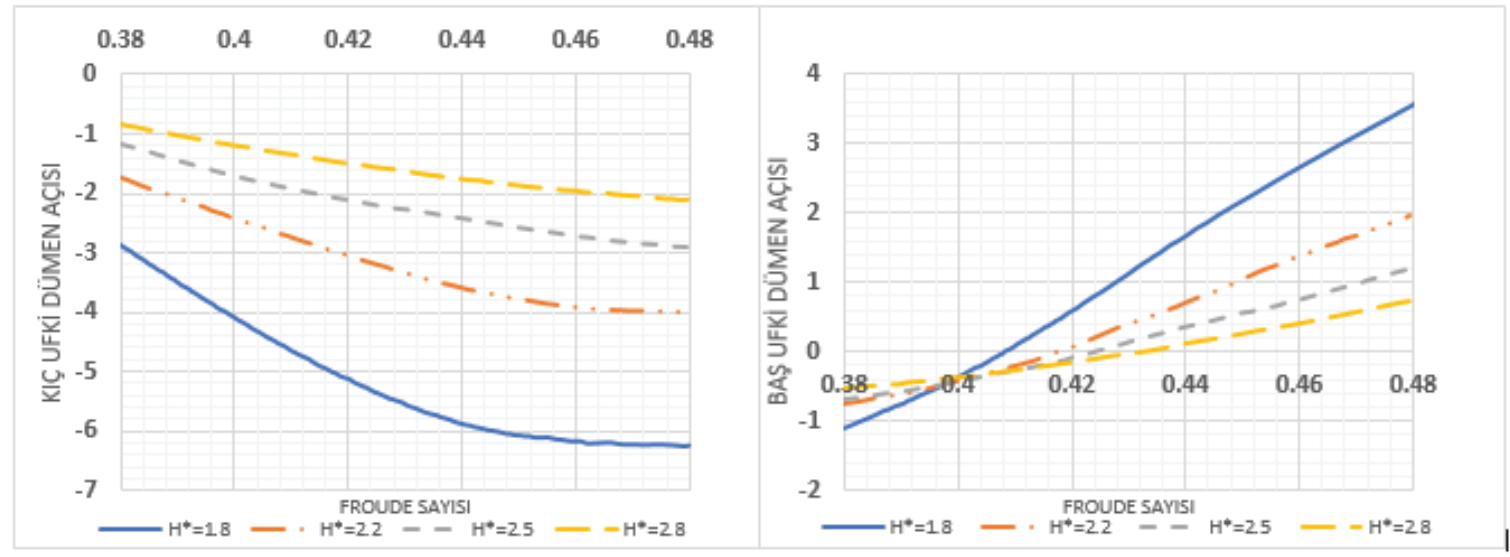

UFKi DÜMENLERIN YELKEN KONFIGÜRASYONU

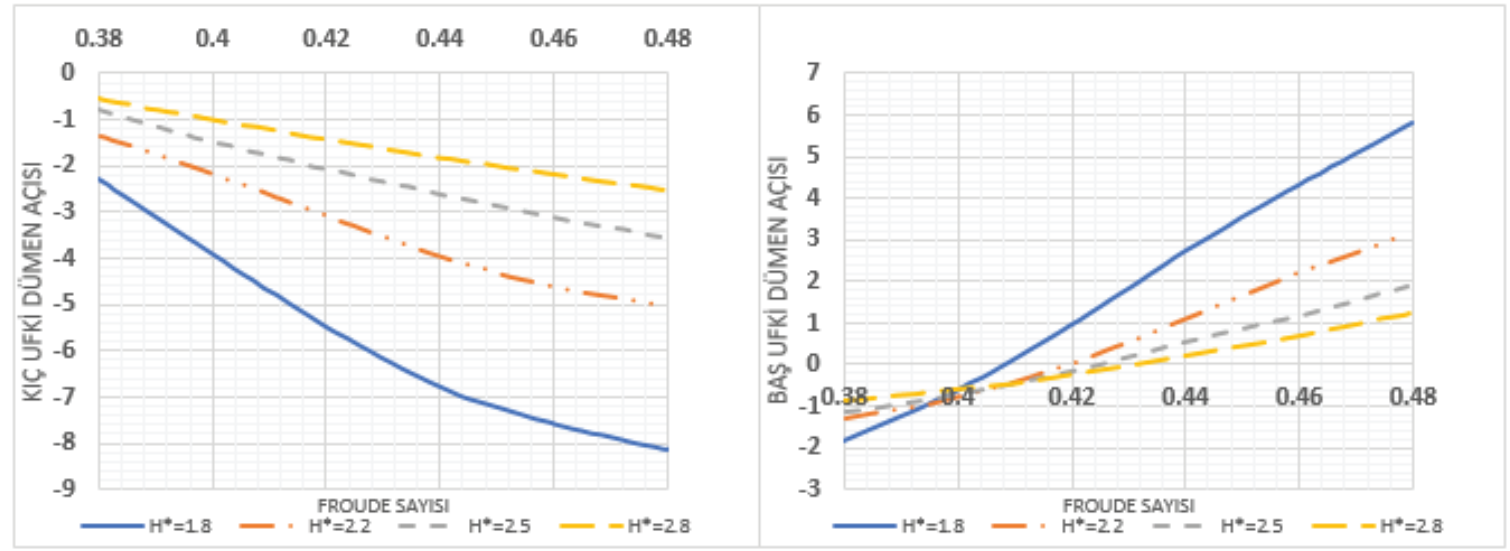

Şekil 6. Farklı derinlikler için, derinliği sabit tutmak amacıyla gerekli ufki dümen (baş ve kıç) açılarının Fr sayısına bağlı değişimi (Renilson vd., 2014)

Daha yüksek dalma derinliklerinde $\left(D^{*}=2.2\right.$ ve 3.3$)$ kaldırma kuvvetinin tepe noktası baş dalga çukurunun kıç omuzluğa denk geldiği hız olan $\mathrm{Fr}=0.462$ 'de gerçekleşmektedir.

Yine dikkat çeken bir diğer etki ise kaldırma kuvveti ve yunuslama momentinin Froude sayısı arttıkça gösterdiği farklı davranışlardır. Froude sayısı arttıkça baş dalgasının boyu artar ve dalga çukuru kıç omuzluktaki düşük basınç alanı ile daha az örtüşür. Buna karşılık dalga tepesinin aracın baş tarafında oluşturduğu yüksek basınç artar ve burada negatif yönlü bir kaldırma kuvveti oluşturarak toplam kaldırma kuvvetinin yön değiştirmesine sebep olur. Buna karşılık momentin Froude sayısı ile artmasının sebebi dalga sistemlerinin etkileşiminin giderek aracın kıç tarafına kayması ve böylece moment kolunun uzamasıdır. 
ISSN: 1300-1973, e-ISSN: 2651-530X, Dergi ana sayfası: http://www.gmoshipmar.org/

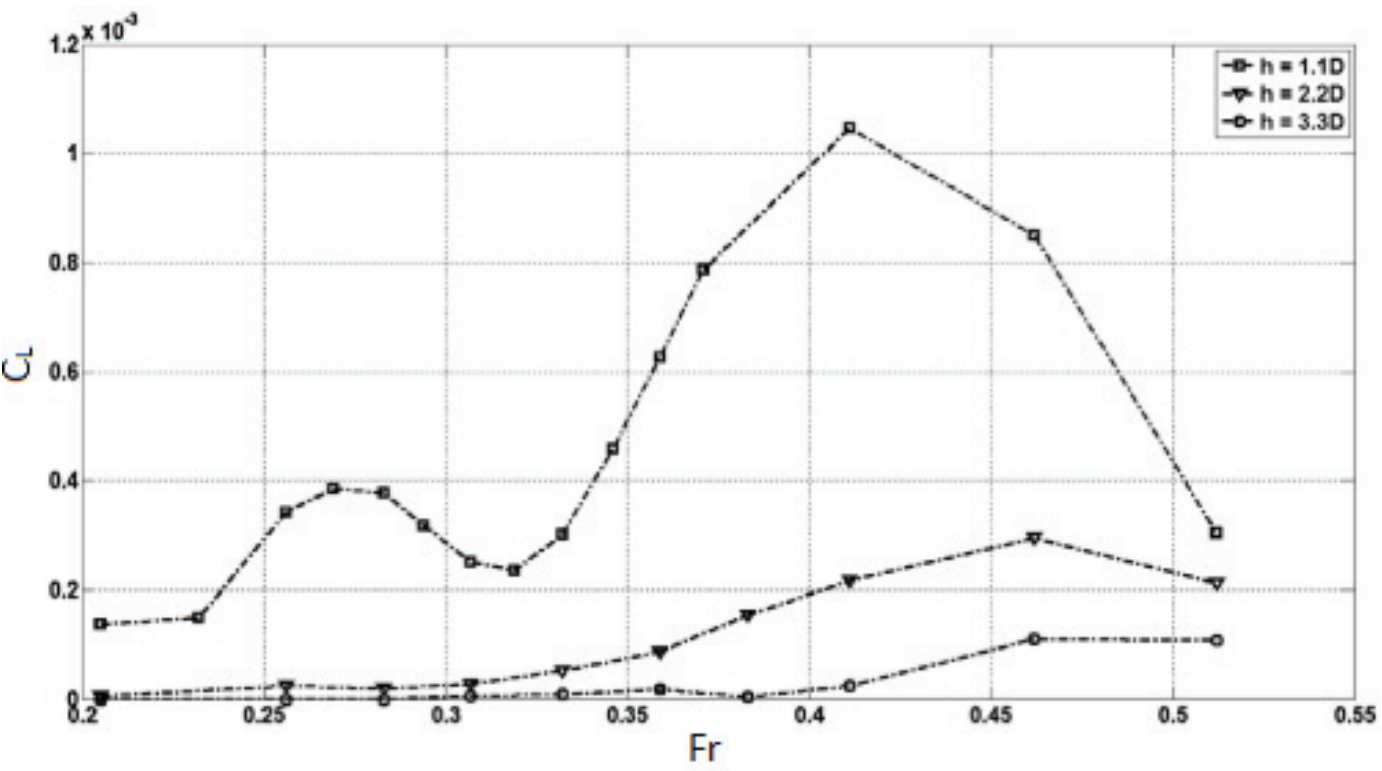

Şekil 7. DARPA Suboff AFF-1 için derinliğe bağlı $C_{L}-F r$ dağılımı (Amiri vd. 2018a)

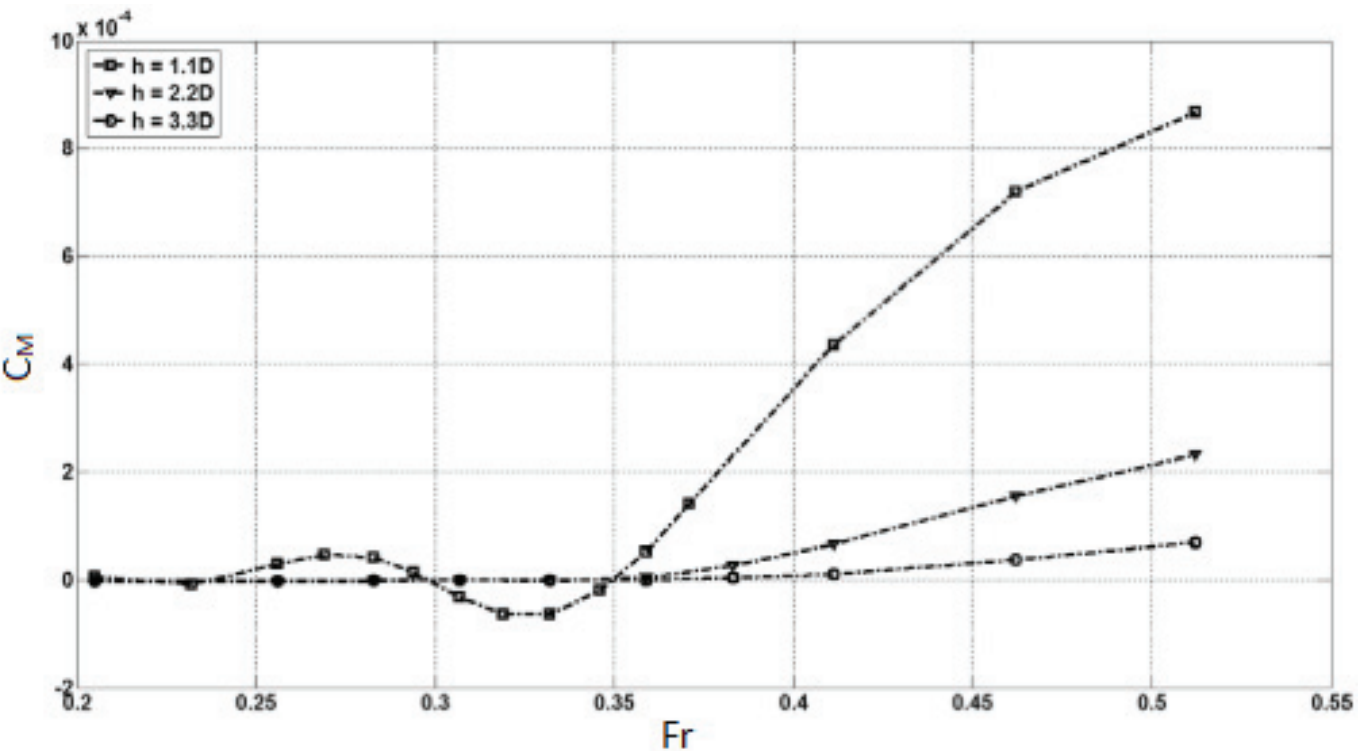

Şekil 8. DARPA Suboff AFF-1 için derinliğe bağı yunuslama momenti katsayısı - Fr dağılımı (Amiri vd. 2018a)

\section{Manevra Karakteristiklerine Etkiler: Yatay Düzlemdeki Etkiler}

Yukarıda da bahsedildiği gibi su altı araçlarının birincil operasyonel işlevlerini yerine getirdikleri derin dalmış durumda yüksek manevra özelliklerine sahip olmaları hedeflenir. Örneğin torpido hücumundan kaçan bir denizaltının küçük dümen açıları ile keskin dönüşler yapabilmesi beklenir. Bu özelliklerin sağlanabilmesi ise düşük dinamik stabilite karakteristikleri anlamına gelecektir. Yani küçük pertürbasyonların (dümenin küçük bir açıyla basılması gibi) etkisi araç tarafından sönümlenmeyerek aracın rotasında büyük değişimlere sebep olacaktır.

Su altı araçları suüstü gemilerinin aksine altı eksende serbestliğe sahip olduklarından dinamik stabilite kavramı gerek yatay gerekse de düşey ekseni kapsar. Ancak bu iki düzlemdeki stabilite isterleri aynı değildir. Yatay düzlemde mümkün olduğunca düşük stabilite özelliklerine sahip olması istenen su altı araçları düşey düzlemde büyük derinlik değişimlerinin aracın bekasını tehlikeye sokacak olması 
nedeniyle daha iyi stabilite özelliklerine intiyaç duyarlar. Birbirinden farklı bu isterlerin her iki düzlemdeki matematiksel ifadesi ise stabilite indeksleri ve dolayısı ile bazı manevra katsayıları ile yapılmaktadır. Saout (2003) Ocean Explorer (OEX) otonom su altı aracının geometrisini ve sınır integral yöntemini kullanarak gerçekleştirdiği ideal akış analizlerinde yatay düzlemde stabiliteye etki eden manevra katsayılarını hesaplayarak aracın bu düzlemlerde stabil olup olmadığını analiz etmiştir. Yazar ayrıca ağırlık merkezinin yerinin ve dümen katsayısının farklı değerlerini de hesaplamalarda göz önüne almış, ayrıca ortam dalgaları nedeniyle oluşan etkileri de modele yansıtarak sonuçları serbest su yüzeyi deformasyonları ve stabilite türevleri cinsinden vermiştir. Hesaplama sonuçlarının stabilite özelinde derin dalmış durum sonuçları ile karşılaştııılması ile yazar serbest su yüzeyinin yatay eksende dinamik stabiliteyi artırdığı sonucuna varmış ancak bu olgunun sebeplerine değinmemiştir.

Serbest su yüzeyi zamana bağlı hız dalgalanmalarını yayınım sönümlemesi ile sönümlemektedir. Saout ve Ananthakrishnan (2011) yukarıdaki çalışmanın devamı niteliğindeki çalışmalarında su altı aracının satıha yaklaştıkça $\left(D^{*}=1.50\right)$ yatay düzlemde stabilite artışını bu sönümleme özelliği ile ilişkilendirmişlerdir. Bu iki çalışmanın sonucunu deneysel olarak destekleyen bir diğer çalışma ise Efremov ve Milanov (2019) tarafından yapılmıştır.

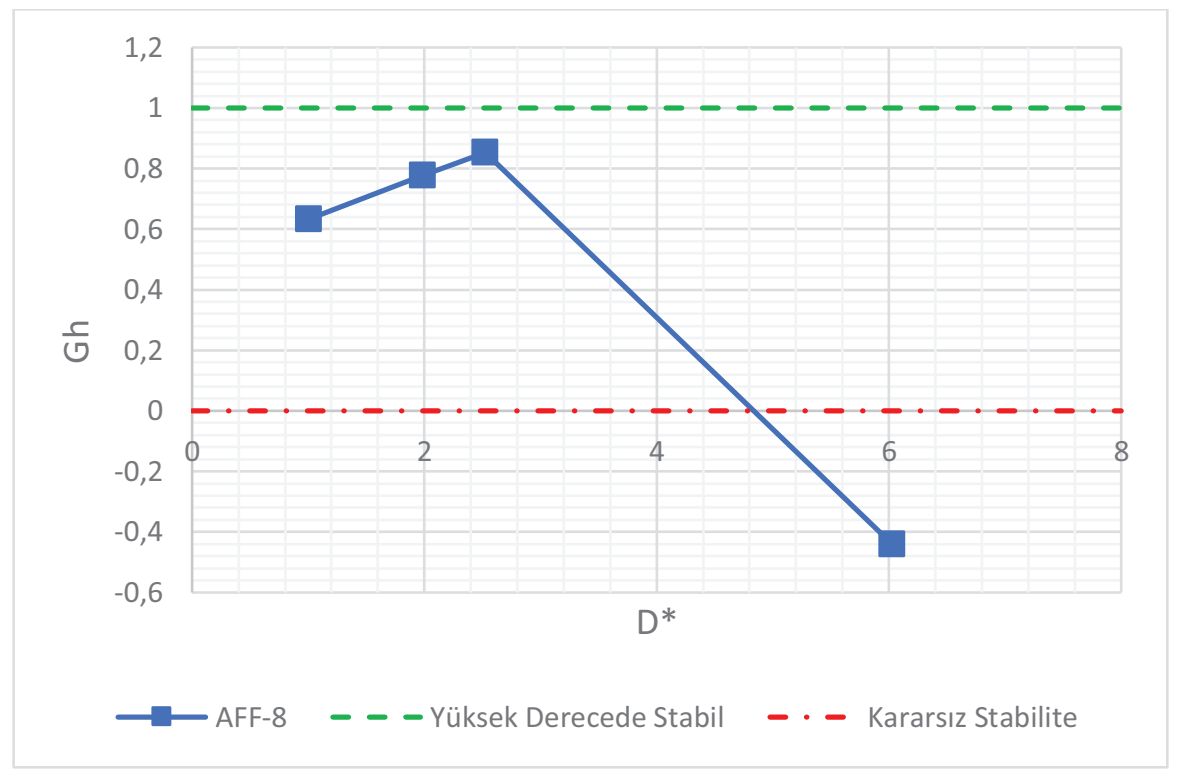

Şekil 9. DARPA Suboff AFF-8 Geometrisi için boyutsuz derinlik - Gh dağılımı (Efremov \& Milanov, 2019)

Yazarlar; DARPA Suboff AFF-8 geometrisi ve üç ayrı derinlik için DHM mekanizması kullanılarak gerçekleştirdikleri deneyler neticesinde aracın yatay düzlem stabilite türevleri ile stabilite indeksini hesaplamışlardır. Hesaplamalar neticesinde denklem (7)'de verilen yatay düzlemde stabilite indeksinin Şekil 9'da gösterildiği gibi derinliğin azalan bir fonksiyonu olduğunu saptamışlardır.

$$
G_{h}=1-\frac{N_{v}^{\prime}\left(Y_{r}^{\prime}-m^{\prime}\right)}{Y_{v}^{\prime}\left(N_{r}^{\prime}-m^{\prime} x_{G}^{\prime}\right)}
$$

Burada;

$G_{h}$ : Yatay düzlem stabilite indeksini

$m^{\prime}$ : Su altı aracının hidrodinamik kütlesini

$x_{G}^{\prime}$ : Su altı aracının ağırlık merkezinin boyuna konumunu 
$N_{v}^{\prime}$ : Savrulma momentinin yan öteleme hızına bağlı değişimini

$Y_{r}^{\prime}$ :Yan öteleme kuvvetinin savrulma açısal hızına bağlı değişimini

$Y_{v}^{\prime}$ :Yan öteleme kuvvetinin yan öteleme hızına bağlı değişimini

$N_{r}^{\prime}$ : Savrulma momentinin savrulma açısal hızına bağlı değişimini

ifade etmektedir.

Yatay düzlemde stabilitenin satıha yaklaştıkça artışının en beklenen sonucu aracın bu düzlemde manevra edilebilirliğinin azalması ve dolayısı ile her bir manevraya ait karakteristik parametrelerin (örneğin dönüş zig-zag manevrası için aşırı sapma açısı vb.) değişmesidir. Dubbioso vd. (2016) satıha yakın $\left(D^{*}=1.75\right)$ yatay düzelmede daimi (steady) dönüş manevrasını incelediği farklı kontrol yüzeyi konfigürasyonuna sahip (" + " ve " $x$ " dümen) su altı araçlarının rotasının serbest su yüzeyinin varlığından etkilenmediği sonucuna ulaşmıştır. Bu bağlamda analizlerini benzer derinliklerde yapmalarına rağmen Dubbioso vd. (2016)'nin elde ettiği bu sonuç Saout ve Ananthakrishnan (2011)'un sonuçları ile çelişmektedir.

Literatürde yatay düzlemde sıklıkla incelenen bir diğer manevra ise statik sürüklenme manevrasıdır. Küçük sürüklenme açısı rejimi $\left(0^{\circ}-4^{\circ}\right)$ için yaptıkları hesaplamalarda Broglia vd. (2006) yatay düzlem kuvvet ve momentlerin serbest su yüzeyinin varlığından pratikte etkilenmediği sonucuna varmışlardır. Analizlerin çok küçük sürüklenme açısı değerleri için yapılmış olduğu ve dolayısı ile akışın yatay düzlem simetrisinin kısmen korunduğu göz önüne alındığında bu beklenen bir sonuçtur.

Sürüklenme açısının kritik eşiğinden daha büyük açılarda akışın çapraz bileşeni (Usin $\beta$ ) giderek daha baskın hale gelmektedir. Derinlikten ve cismin geometrisinden bağımsız olarak bu hız bileşenindeki artış dalmış cisimlerin yüzeyindeki basınç dağılımının aşağıdaki ortak özellikleri gösterecek şekilde değişmesine ve cismin yatay yönde kuvvet ve momentlere maruz kalmasına sebep olur (Amiri vd. 2019)

- Baş durgunluk noktasının rüzgarüstü tarafa kayması ve neticede dinamik basıncın rüzgarüstü taraf baş omuzlukta yukarı, rüzgaraltı taraf baş omuzlukta ise aşağı yönlü değişmesi,

- Kıç durgunluk noktasının rüzgaraltı tarafa kayması ve neticede rüzgarüstü taraf kıç omuzlukta dinamik basıncın azalması,

- Rüzgaraltı kıç tarafta oluşan girdapsı yapılar nedeniyle bu bölgede dinamik basıncın azalması,

Bu değişimlerin açık su manevra karakteristiklerine olan etkileri birçok araştırmacı tarafından detaylı bir şekilde incelenmiştir. Bu alandaki güncel çalışmalara (Zhang vd., 2013), (Phillips vd., 2010) ve (Kim vd., 2013) örnek gösterilebilir.

Statik sürüklenme halindeki su altı aracının serbest su yüzeyine yaklaşması; serbest su yüzeyinin aracın akışa göre açısal oryantasyonu sebebi ile değişmiş bir dinamik basınç alanı ve aracın rüzgaraltı tarafındaki girdapsı yapıların oluşturduğu alçak basınç alanı ile karşılıklı etkileşime girmesine yol açar. Bu karşılıklı etkileşim aracın hidrodinamik davranışı üzerinde baskın olan baş-kıç omuzluk dalgası etkileşimini (Amiri vd., 2018a) daha da karmaşık hale getirmesi ve araca etkiyen yatay düzlem kuvvet ve momentlerinde ( $\mathrm{Y}$ ne $\mathrm{N}$ ) değişime sebep olması beklenir.

Aracın açısal oryantasyonu sebebiyle sırasıyla rüzgarüstü baş omuzluk rüzgaraltı kıç omuzluğa doğru yer değiştiren baş ve kıç durgunluk noktaları arasındaki basınç farkı yanal öteleme kuvvetinin (Y) oluşmasına sebep olur. Serbest su yüzeyinin varlığı durumunda yanal öteleme kuvveti; 
- Rüzgarüstü taraftaki yüksek basınç alanının yüzeyi yukarı yönlü itmesinin bu bölgede basıncı artırması,

- Rüzgaraltı taraftaki girdapsı yapılar ile rüzgaraltı kıç omuzluktaki alçak basınç alanının bileşkesinden kaynaklanan alçak basınç alanının ise serbest su yüzeyinin aşağı doğru deforme etmesinin bu bölgede basıncı daha da düşürmesi,

ve neticede her iki taraf arasındaki dinamik basınç farkının büyümesi sebebiyle artacaktır. Başka bir ifade ile statik sürüklenme manevrası icra eden su altı aracı serbest su yüzeyine ne kadar yakınsa maruz kalacağı yanal öteleme kuvveti de o oranda artmaktadır.

Amiri vd. (2018b) yukarıda yanal öteleme kuvveti için vardıkları sonucu serbest su yüzeyinin varlı̆̆ı nedeniyle savrulma momentindeki $(\mathrm{N})$ değişimi açıklayabilmek için kullanmışlar, bunun için yanal öteleme kuvvetinin boy doğrultusundaki dağııımını aracın açık su ve serbest su yüzeyi etkisi altındaki durumları için Şekil 10'da gösterildiği gibi plotlayarak çalışmalarında göstermişlerdir.

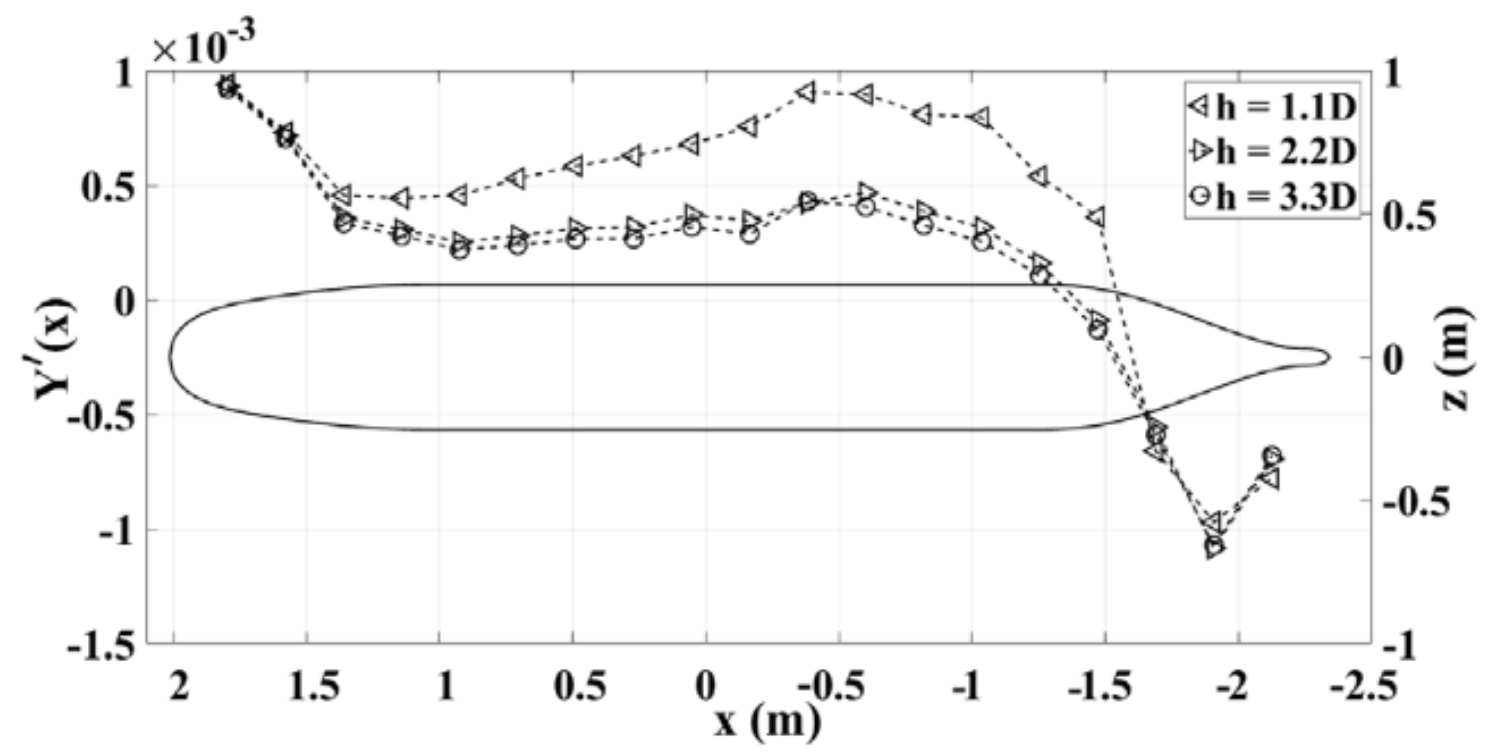

Şekil 10. Farklı derinlikler için yan öteleme kuvvetinin boy doğrultusunda dağııımı (Amiri vd., 2018b)

Şekil 10'dan görülebileceği üzere derin dalmış durumda yanal öteleme kuvvetine su altı aracının baş tarafına yakın kesitler daha fazla katkı sunarken, serbest su yüzeyine yaklaştıkça çapraz akış ayrımasının sebep olduğu rüzgaraltı kıç omuzluk girdap çiftinin serbest su yüzeyi ile etkileşimi yanal öteleme kuvvetinin üretimine kıç tarafa yakın kesitlerin daha fazla katkı sağlamasına yol açar. Bu kesitlerin neden olduğu yanal öteleme kuvvetindeki artış ise negatif yönlü bir savrulma momenti oluşturur. Derin dalmış durumda pozitif işaretli olan savrulma momenti bu negatif yönlü etki sebebiyle yanal öteleme kuvvetinin aksine derinliğin artan bir fonksiyonu olur. Kıç kesitlerin satıha yaklaştıkça yatay düzlemde kuvvet ve momentlere olan bu etkileri serbest su yüzeyiyle etkileşim halinde olan bir su altı aracının manevra karakteristikleri üzerinde kıça yakın kesitlerin baskın bir etkisi olduğunu göstermektedir.

Yatay düzlem büyüklüklerinin derinliğe bağlı değişim bilgisi kullanılarak ulaşılabilecek bir diğer sonuç ise daha önce Saout (2003) ve Saout ve Ananthakrishnan (2011) tarafından potansiyel teoriye dayalı, 
ISSN: 1300-1973, e-ISSN: 2651-530X, Dergi ana sayfası: http://www.gmoshipmar.org/

Efremov ve Milanov (2019) tarafından ise deneysel yöntemler kullanılarak gösterilen satıha yaklaştıkça aracın yatay düzlem stabilitesindeki artışın sebepleridir. Amiri vd. (2019) stabilitedeki bu değişimi yanal öteleme "v" ve açısal savrulma "r" hızlarının oluşturduğu hidrodinamik momentlerin moment kollarındaki (sırasıyla $I_{v}$ ve $I_{r}$ ) değişim ile açıklamışlardır. Yatay düzlemde stabilite kriterini veren denklem (8)'deki ifade söz konusu moment kolları cinsinden;

$$
\underbrace{\frac{N_{r}^{\prime}-m^{\prime} x_{G}}{Y_{r}^{\prime}-m^{\prime}}}_{l_{r}}-\underbrace{\frac{N_{v}^{\prime}}{Y_{v}^{\prime}}}_{l_{v}}>0
$$

Denklem (6)'da gösterildiği gibi yazılabilir.

$$
l_{r}-l_{v}>0
$$

Buna göre satıha yaklaştıkça yanal öteleme hızı (v) tarafından yaratılan yanal öteleme kuvvetinin artarak N momentinin azalması bu hızdan kaynaklanan momentin moment kolunu küçültecektir.

Açısal savrulma hızı nedeniyle oluşan $\mathrm{Y}$ kuvveti ve $\mathrm{N}$ momenti ise satıha yaklaştıkça benzer bir artış eğilimi gösterdiği için yukarı yönde bir miktar değişecektir. Denklem (9)'da moment kolları cinsinden verilen yatay düzlem stabilite kriteri göz önünde bulundurulduğunda moment kollarındaki anılan değişimler aracın dinamik stabilitesinin iyileşmesi, dolayısı ile aracın manevra edilebilirliğinin azalması anlamına gelecektir.

Serbest su yüzeyinin etkisi ile yatay düzlem dinamik stabilite özelliklerindeki bu iyileşmenin nedenlerine ilave olarak iyileşmenin bu düzlemde gerçekleştirilen manevraları nasıl etkilediği de incelenmelidir. Bu noktaya kadar sunulan sonuçlardan her ne kadar yatay düzlemde aracın manevra edilebilirliğinin azalacağı yönünde genel bir kanıya ulaşmak mümkünse de bu analizlerin yapılması hareketin fiziğinin anlaşılması açısından önemlidir. Bu kapsamda daimi dönüş ve zig-zag $\left(10^{\circ} / 10^{\circ}\right)$ manevralarının değişik derinlikler için yörüngeleri Amiri vd. (2019) tarafından analiz edilmiştir.

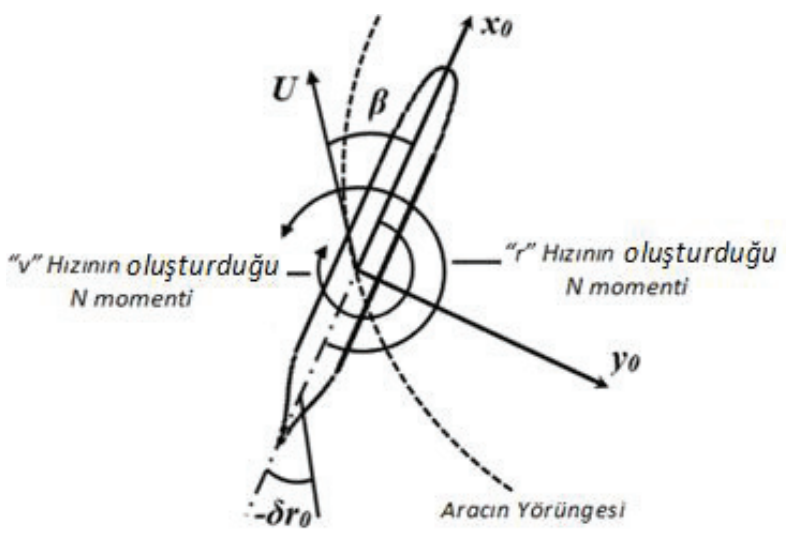

Şekil 11. Serbest su yüzeyine yakın yatay düzlemde $\delta r 0$ dümen açısı ile dönüş yapan araç (Amiri vd., 2019)

Yazarlar aracın manevra edilebilirliğinin azalacağı yönündeki genel kanıyı inceledikleri;

- Daimi dönüş manevrası için; taktik çap, ilerleme ve yanlama mesafelerinin arttığını,

- Zig-zag manevrası için; overshoot mesafesinin azaldığını, 
göstererek desteklemişlerdir. Yazarlar ayrıca su altı aracının manevra edilebilirliğindeki bu azalmayı efektif sürüklenme açısındaki ( $\beta$ ) azalma ile açıklamışlardır. Buna göre manevra edilebilirlikteki azalma serbest su yüzeyi ile etkileşimin bir sonucu olarak aynı amudi dümen açısı ile daha küçük sürüklenme etkisi elde edilebilmesinden kaynaklanmaktadır.

Serbest su yüzeyine yaklaştıkça savrulma momentinin (N) yan öteleme hızından (v) kaynaklanan bileşeni azalarak savrulma açısal hızından ( $r$ ) kaynaklanan bileşeni artacaktır (Şekil 11) Neticede birbirine zıt yönlü bu iki etkinin bileşkesi giderek azalacaktır. Düşey (amudi) dümen açısı sabit kalsa dahi yaratacağı sürüklenme etkisi daha az olacak ve neticede su altı aracının yatay düzlemde manevra edilebilirliği azalacaktır.

\section{Serbest Su Yüzeyinin Varlığı Nedeniyle Oluşan Düzlem Dışı Etkileşimler}

Bir su altı aracı serbest su yüzeyine yaklaştıkça düşey düzlemde, sürüklenme açısı arttıkça da yatay düzlemde hangi ilave kuvvet ve momentlere maruz kalacağı sebepleri ile birlikte Bölüm 6 ve Bölüm $7^{\prime}$ da incelenmiş olup, bu incelemeler her bir durum için diğerinin etkisi olmaksızın yapılmıştır.

Bununla birlikte serbest su yüzeyine yakın statik sürüklenen bir su altı aracının rüzgaraltı tarafında oluşan girdapsı yapıların yüzeyle etkileşimi aracın yalnızca yatay düzlemde maruz kaldığı kuvvet ve momentlerin derin dalmış durumdan farklı olmasına değil aynı zamanda düşey düzlemde serbest su yüzeyi etkisi ile oluşan kuvvet ve momentlerin de $\beta=0^{\circ}$ durumundan farklı olmasına yol açacaktır.

Çalışmalarında çapraz akış ayrılması kaynaklı girdaplar ile serbest su yüzeyi etkileşiminin bu düzlem dışı (out-of-plane) etkilerine yer veren Amiri vd. (2018b) DARPA Suboff AFF-1 geometrisi için $\mathrm{Fr}=0.512$ 'de ve $D^{*}=1.1-\infty$ aralığındaki derinliklerde $X, Z$ kuvvetleri ile $M$ momentinin derinliğe ve sürüklenme açısına $\left(\beta=0^{\circ}-18.11^{\circ}\right)$ bağlı değişimini incelemişlerdir.

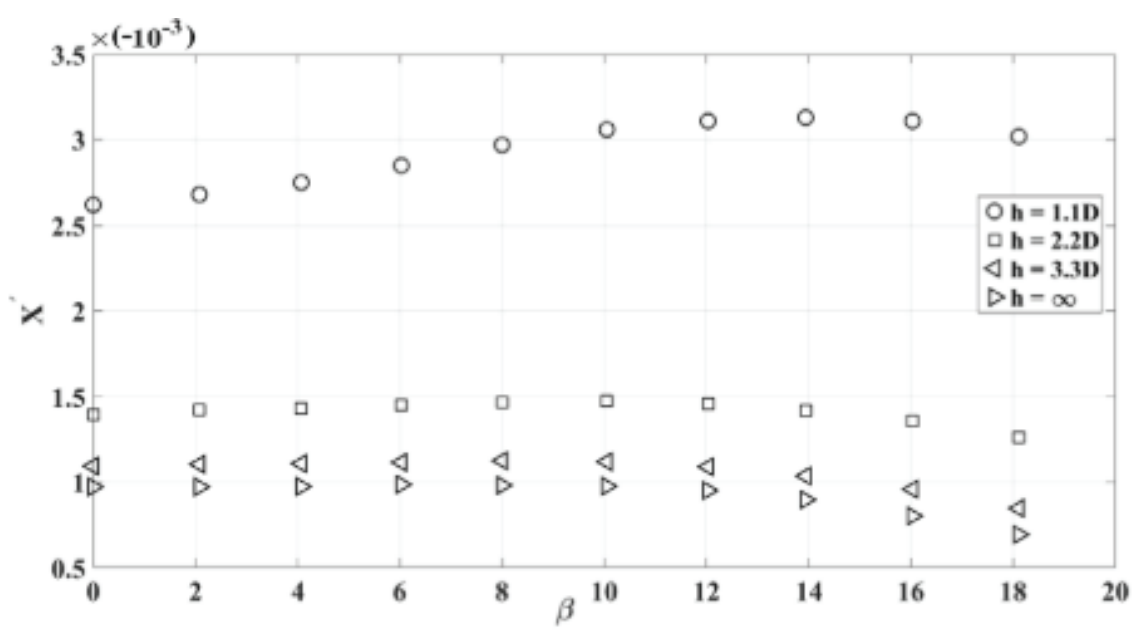

Şekil 12. Farklı derinlikler için DARPA Suboff AFF-1'e etkiyen " $X$ " kuvvetinin $\beta^{\prime}$ ya göre değişimi (Amiri vd., 2018b)

Buna göre yazarlar;

- Derin dalmış durumun aksine sürüklenme açısındaki artışın X yönündeki kuvveti Şekil $12^{\prime}$ de gösterildiği gibi artırdığını, 
- En küçük dalma derinliği için ( $\left.D^{*}=1.1\right)$ Z kuvvetinin Şekil $13^{\prime}$ te gösterildiği gibi $\beta=10^{\circ}$ ye kadar yukarı yönlü (pozitif) ve sürüklenme açısının azalan, bu değerden büyük açılarda ise aşağı yönlü (negatif) ve sürüklenme açısının artan bir fonksiyonu olduğunu,

- En küçük dalma derinliği için $\left(D^{*}=1.1\right) \mathrm{M}$ momentinin Şekil $14^{\prime}$ te gösterildiği gibi $\beta=10^{\circ}$ ye kadar sürüklenme açısındaki artıştan etkilenmediğini, bu değerden büyük açıların ise baş aşağı (pozitif) yönlü olan momentin büyüklüğünün azalmasına sebep olduğunu,

tespit etmişlerdir.

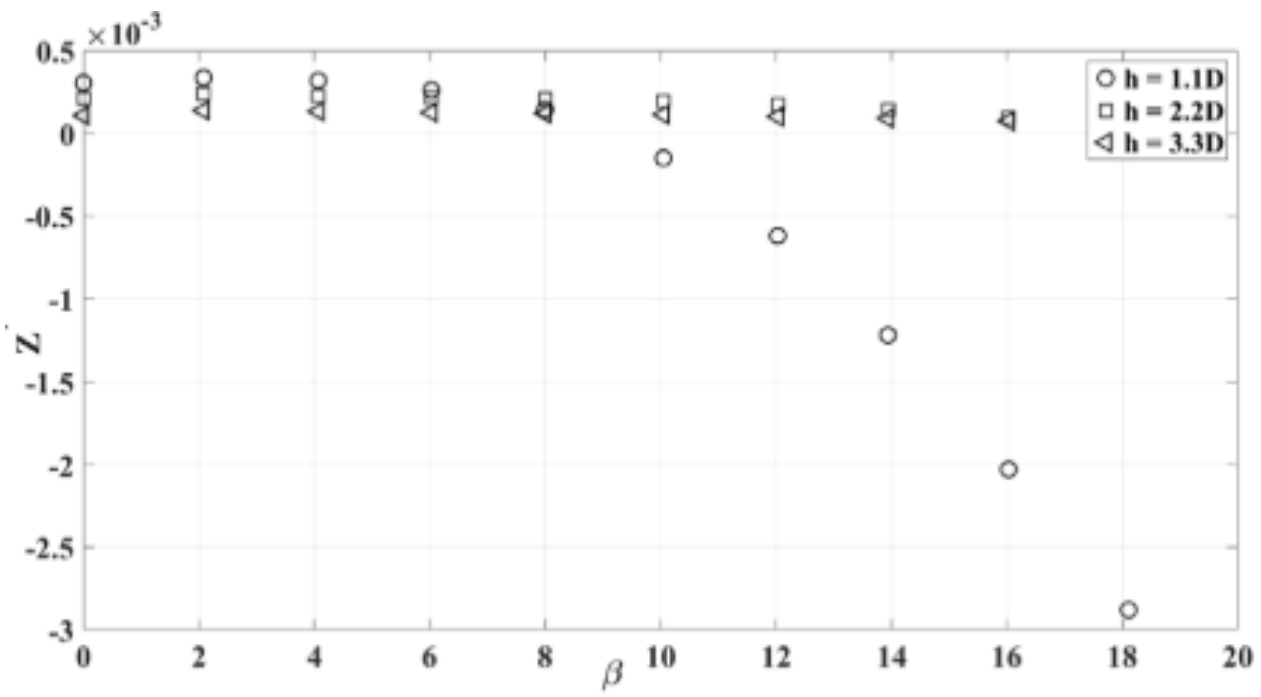

Şekil 13. Farklı derinlikleri için DARPA Suboff AFF-1'e etkiyen " $Z$ " kuvvetinin $\beta^{\prime}$ ya bağlı değişimi (Amiri vd., 2018b)

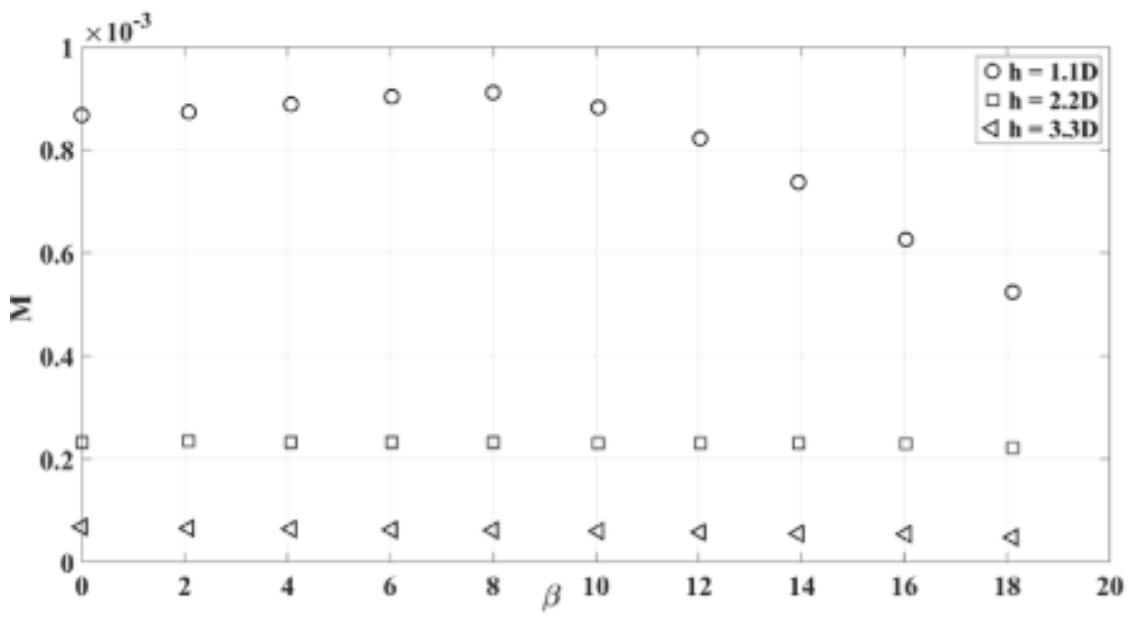

Şekil 14. Farklı derinlikleri için DARPA Suboff AFF-1'e etkiyen “M" momentinin $\beta$ 'ya bağlı değişimi (Amiri vd., 2018b)

Z kuvveti ve $\mathrm{M}$ momenti için bu değişimlerin sebebini inceleyen yazarlar, serbest su yüzeyine yaklaştıkça özellikle aracın kıç kısmına yakın kesitlerde Z kuvveti dağılımının Şekil 15'teki gibi ciddi bir şekilde değiştiğini saptamışlardır. Buna göre rüzgarüstü taraftaki durgunluk noktası üzerinde yukarı yönlü deforme olan serbest su yüzeyi rüzgarüstü yüksek basınç alanının rüzgaraltı tarafa doğru genişlemesine sebep olur. Öte yandan rüzgaraltı girdapsı yapıların serbest su yüzeyini aşağı doğru 
deforme etmesinin düşürdüğü dinamik basınç, rüzgaraltı tarafta oluşan ters (adverse) basınç gradyeninin büyüklüğünü azaltarak çapraz akış ayrılmasının gecikmesine ve rüzgaraltı alçak basınç alanının daha da küçülmesine sebep olur. Bu iki olgu beraber değerlendirildiğinde, sürüklenme açısı arttıkça çapraz akış kaynaklı aşağı yönlü Z kuvvetinin düşey düzlem simetrisinin bozulması sebebiyle oluşan yukarı yönlü Z kuvvetini domine ettiği sonucuna varılabilir. Böylece bileşke kuvvetin $\beta=10^{\circ}$ civarında yön değiştirmesi ve dolayısı ile $M$ momentindeki Şekil $16^{\prime}$ da görülen sürüklenme açısına bağı azalma eğilimi açıklanabilir.

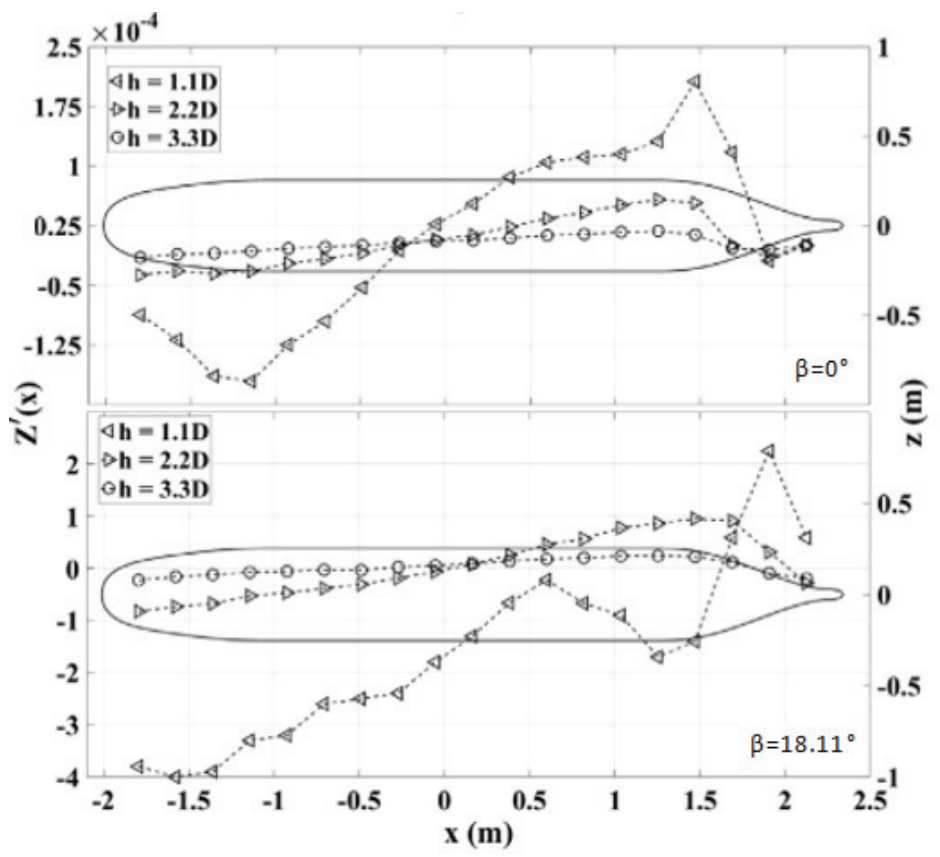

Şekil 15. Farklı derinlikler ve sürüklenme açısının asgari ve azami değerleri için DARPA Suboff AFF-1 geometrisinin maruz kalacağı dalıp-çıkma kuvvetleri (Amiri vd., 2018b)

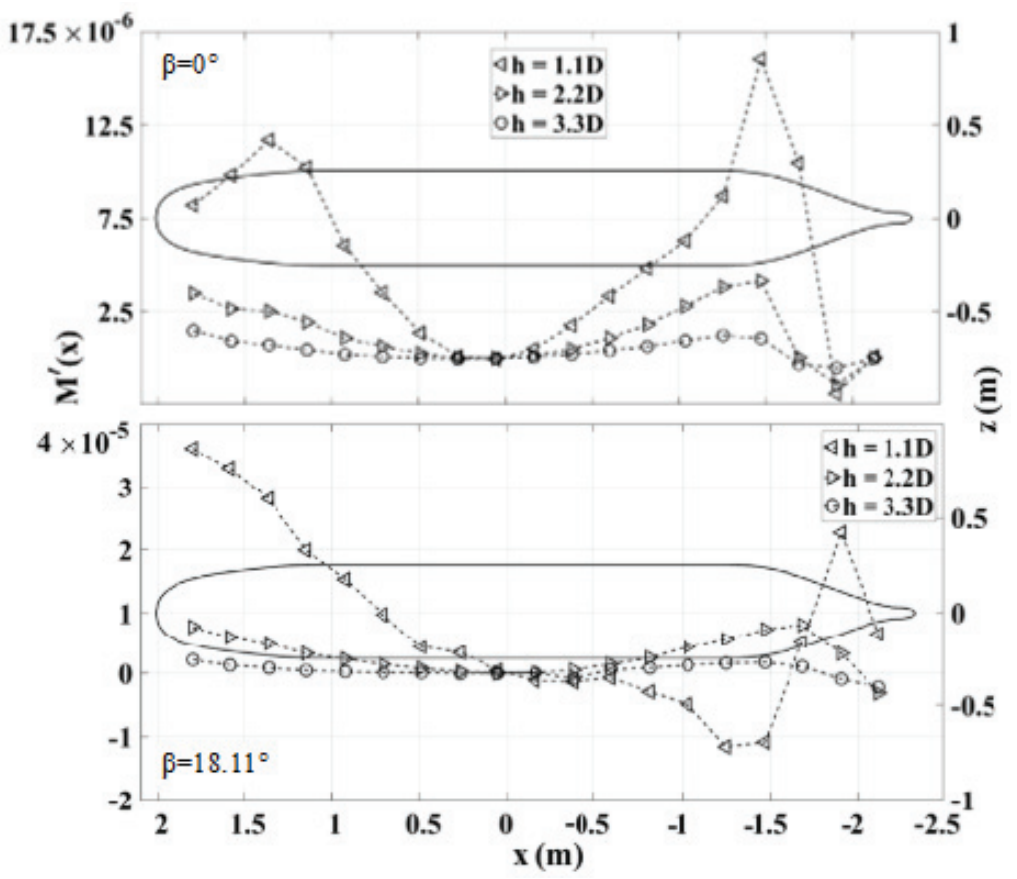

Şekil 16. Farklı derinlikler ve sürüklenme açısının asgari ve azami değerleri için DARPA Suboff AFF-1 geometrisinin maruz kalacağı yunuslama momenti (Amiri vd., 2018b) 


\section{Serbest Su Yüzeyinin Takıntılar Ille Etkileşimi}

Serbest su yüzeyinin su altı aracının dinamik stabilitesine ve manevra edilebilirliğine olan etkilerinin bir diğer boyutu da kontrol yüzeylerinin verimindeki olası değişikliklerdir. Herhangi bir yönde hareket ettirilmese bile kontrol yüzeylerinin aracın konfigürasyonuna eklenmesinin veya var olan kontrol yüzeylerinin boyutunun artırımasının dinamik stabiliteyi olumlu etkilediği (Amiri vd., 2019) bilinmekle birlikte bizzat bu yüzeylerin açısal oryantasyonu nedeniyle oluşturduğu kuvvetlerin serbest su yüzeyinden nasıl etkilendiği yakın zamanda Efremov ve Milanov tarafından deneysel olarak araştırılmıştır. DARPA SUBOFF AFF-8 konfigürasyonunun yatay düzlem manevra edilebilirliği üzerindeki etkilerini göstermek için amudi dümenin üç farklı boyutsuz dümen derinliğinde $\left(D_{R}{ }^{*}=H / h_{R}\right)$ ve $0^{\circ}, 5^{\circ}, 15^{\circ}$ ve $35^{\circ}$ dümen açılarında yarattığı kaldırma kuvveti ve maruz kaldığı direnci inceleyen yazarlar dümen performansının (yarattığı kaldırma kuvveti) serbest su yüzeyine yaklaştıkça azaldığını ve maruz kaldığı direncin arttığını tespit etmişlerdir. Yazarlar ayrıca bu etkilerin yüksek dümen açılarında daha belirgin olduğunu vurgulamışlardır.

Amiri vd. (2019)'nin derinlikten bağımsız sabit bir dümen kuvveti kullanarak elde ettiği "satıha yaklaştıkça aracın yatay düzlem stabilitesindeki artış neticesinde aynı dümen açısının daha küçük sürüklenme açılarına sebep olduğu" yönündeki sonucu bu çalışmanın sonuçları ile birlikte değerlendirildiğinde; serbest su yüzeyinin yatay düzlem kuvvet ve momentleri üzerine etkisi nedeniyle azalmış olan manevra edilebilirliğin, amudi dümen verimindeki serbest su yüzeyi kaynaklı düşüş sebebiyle bir miktar daha azalacağı öngörülmektedir.

Takıntıların serbest su yüzeyi deformasyonları ve dolayısıyla kuvvet ve momentler üzerine olan etkileri konusunda ise literatürde farklı sonuçlar mevcuttur. Griffin (2002) takıntıların serbest su yüzeyi dalgalarının genliklerini artırıcı etkisi olduğu dolayısı ile cisme etkiyen kuvvet ve momentlerde de artışa sebep olduklarını savunmuştur. Liu ve Guo (2013) ise yelkenin varlığı nedeniyle baş dalgasının dalga tepesinin kıça, yelkenin olduğu noktaya doğru kayacağını öne sürmüş, dolayısı ile yüzey dalgasının yapısının yelkenin yeri değiştirilerek değiştirilebileceğini iddia etmiştir. Polis vd. (2013b) serbest su yüzeyiyle etkileşim halindeki DARPA Suboff AFF-1 ve AFF-2 geometrilerinin düşey düzlem kuvvet ve momentlerini kıyaslayarak yelkenin serbest su yüzeyiyle etkileşiminin bu büyüklüklerin derinliğe bağlı azalma karakteristikleri üzerinde farklılılara sebep olabileceğini öne sürmüşlerdir.

Her üç çalışmanın takıntıların serbest su yüzeyi deformasyon şekilleri üzerinde etkili olduğu yönündeki sonuçlarının aksine Shariati ve Mousavizadegan (2017) DARPA Suboff AFF-1 ve AFF-8 geometrilerini $D^{*}=1.3^{\sim} 4.4$ derinlik ve $\mathrm{Fr}=0.128 \sim 0.84$ aralığında analiz ettiği çalışmalarında takıntıların varlığının serbest su yüzeyi dalga paternleri ve dolayısı ile düşey düzlem kuvvet ve momentleri üzerinde belirgin bir etkisi olmadığını sonucuna varmışlardır.

\section{Serbest Su Yüzeyinin Sevk Parametrelerine Etkileri}

Serbest su yüzeyi ile etkileşimin cismin manevra karakteristikleri açısından incelenmesi gereken bir diğer boyutu da sevk parametrelerinin söz konusu bu etkileşim altında değişimleridir. Genellikle bu değişimler serbest su yüzeyinin diğer etkilerine göre (eksenel kuvvet, kaldırma kuvveti vb.) çok daha küçük olduğundan (Zhang ve Zhang, 2014) bu konudaki literatür birbirinden bağımsız birkaç spesifik çalışmadan ibarettir.

Serbest su yüzeyi etkisi altında tekne-pervane etkileşiminin nasıl değiştiğini saptamayı hedefledikleri çalışmalarında Zhang ve Zhang (2014) iz katsayısı " $w$ " ve itme azalması katsayı " $t$ "larının dalmış durum ve satıha yakın analiz koşullarındaki değerlerini karşılaştırarak literatürde bu alanda bilinen ilk çalışmayı 
gerçekleştirmişlerdir. Yazarlar su altı aracının kritik dalma derinliğinden daha yukarıda olduğu durumlarda bile yukarıda anılan pervane-tekne etkileşim parametrelerinin Şekil 17'den de görülebileceği üzere bu durumdan çok az etkilendiğini tespit etmişler ve sevk parametrelerinin serbest su yüzeyinin varlığından etkilenme kriterinin tekne için geçerli olan kriterden farklı olduğunu öne sürmüşlerdir. Buna göre serbest su yüzeyi etkilerinin sevk parametreleri açısından kritik olduğu derinliğin ITTC tarafından suüstü gemileri için önerilen kriterlerle (ITTC-Specialist Committee, 2002) analojik olarak pervane çapı cinsinden denklem (10)'da gösterildiği şekilde ifade etmişlerdir.

$$
D_{S}^{*}=\frac{d_{\text {shaft }}}{D_{\text {prop }}} \geq 1.5
$$

Denklem (10)'da $\mathrm{d}_{\text {shaft }}$ pervane şaft merkezinin derinliğini, $\mathrm{D}_{\text {prop }}$ pervane çapını ve $\mathrm{D}_{\mathrm{s}}^{*}$ pervane şaft merkezinin boyutsuz dalma derinliğini ifade etmektedir. Yazarlar başka bir deyişle modern denizaltıların şnorkel/periskop derinlikleri ve pervane çapları dikkate alındığında sevk parametrelerinin bu operasyonlar sırasında serbest su yüzeyinin varlığından etkilenmediği sonucuna varılabilir.

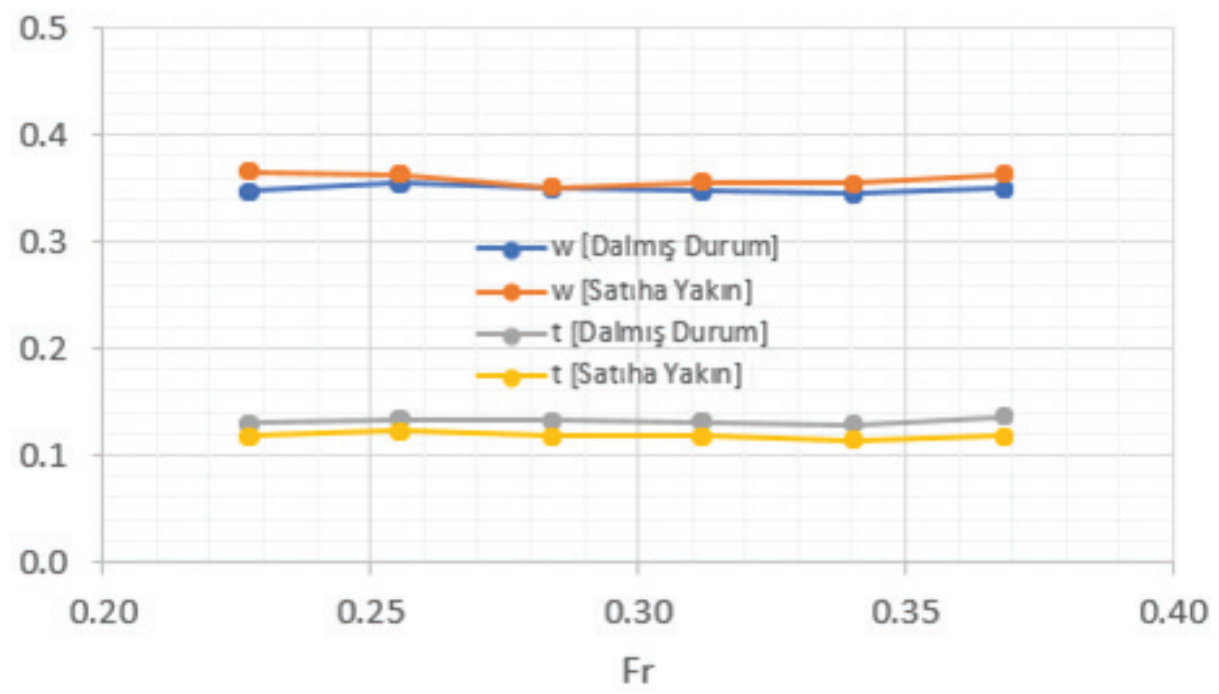

Şekil 17. " $w$ " ve " $t$ " katsayılarının derinliğe ve Froude sayısına bağlı değişimi (Zhang \& Zhang 2014)

Satıha yakın klasik operasyonların yanında özellikle serbest su yüzeyinin yarılması ile neticelenen emercensi satıh manevrası gibi dinamik manevralar pervanenin serbest su yüzeyine kritik derinlikten daha fazla yaklaşmasına sebep olabilir. Vali vd. (2018) kritik derinlikten daha küçük derinliklerde $\left(D^{*}=\right.$ 0.9) pervane karakteristiklerinin ve tekne-pervane etkileşim parametrelerinin değişimini deneysel ve sayısal olarak incelemiştir. Buna göre serbest su yüzeyine kritik derinlikten daha fazla yaklaşmanın pervane itme katsayısını " $\mathrm{K}_{T}$ " düşüreceğini ve benzer bir etkiye itme azalma katsayısı "t" (\%19) ve iz katsayısı "w" (\%7) için de sebep olacağı sonucuna varmışlardır (Şekil 18).

Bu alandaki bir diğer deneysel çalışma da serbest hareketli jenerik bir denizaltı modeli (Joubert BB2) kullanarak Carrica vd. (2019) tarafından gerçekleştirilmiştir. Derin dalmış ve satıha yakın derinlikler için sabit ilerleme hızı şartının sağlandığı deney sonuçlarından yazarlar serbest su yüzeyine yaklaştıkça pervane açısal hızının ve itmesinin artan dirence bağlı olarak artması gerektiği (pervane veriminin azalması) bunun da $\mathrm{K}_{\mathrm{T}}$ ve $\mathrm{K}_{\mathrm{Q}}$ değerlerinin bir miktar artmasına sebep olarak pervanenin daha yüklü çalışmasına neden olacağı sonucuna varmışlardır. 
ISSN: 1300-1973, e-ISSN: 2651-530X, Dergi ana sayfası: http://www.gmoshipmar.org/
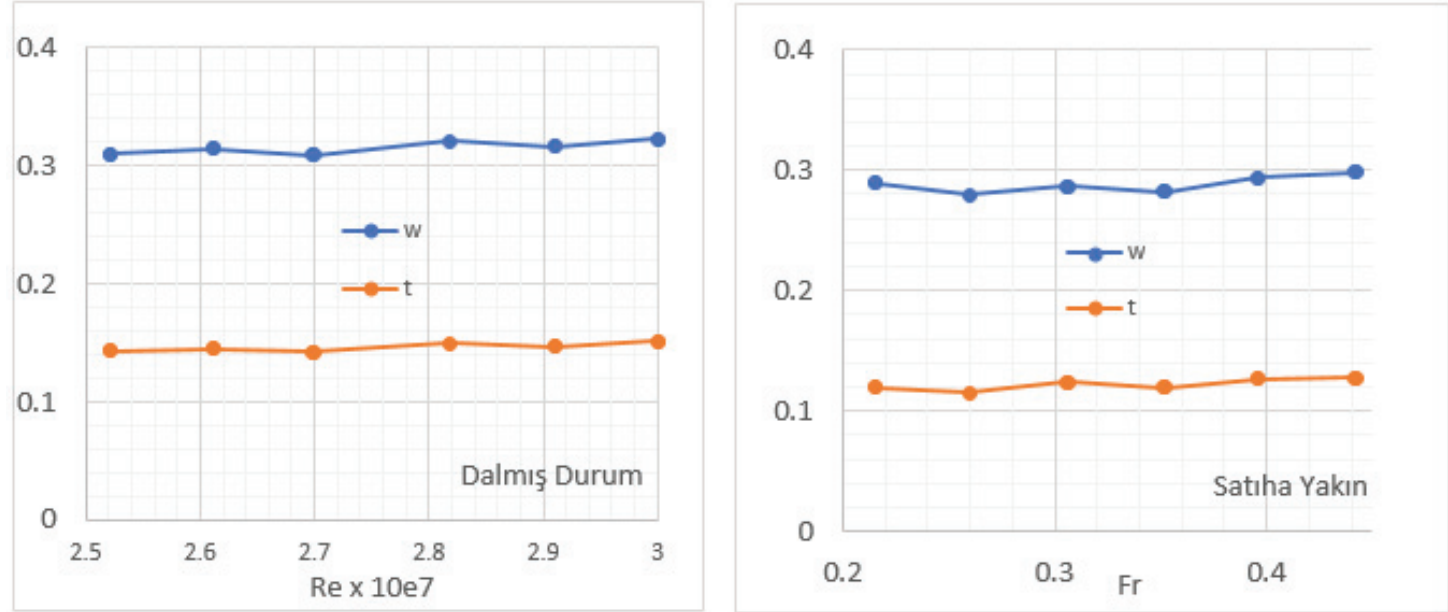

Şekil 18. Jenerik bir denizaltı ve stok pervane için dalmış ve satıha yakın durumlarda " $t$ " ve " $w$ " katsayılarının karşılaştırılması (Vali vd., 2018).

Wang vd. (2020) serbest yüzeyin etkilerini pervaneye gelen akış ve pervane izindeki değişimlere bağlı olarak incelemişlerdir. Farklı derinlik ve ilerleme katsayısı değerlerinin kullanıldığı çalışmanın sonucunda yazarlar serbest su yüzeyine yaklaştıkça her iki akış bölgesinin de önemli ölçüde değiştiği sonucuna varmışlardır. Yazarlar pervane kanatlarının maruz kaldığı yüklerin akış sahasındaki bu değişiklikler sebebiyle arttığını belirlemişlerdir. Bu sonuç Carrica vd. (2019) tarafından ulaşılan sonuçlarla tutarlıdır.

Satıha yaklaştıkça derinliğe bağı olarak azalan hidrostatik basınç ve hızın sabit tutulabilmesi için pervanenin daha yüklü çalışma zorunluluğu bir araya geldiğinde kavitasyonun bir problem olarak ortaya çıkma ihtimali artmaktadır.

\section{Deniz Tabanının Su altı Aracının Manevrasına Etkileri}

Su altı araçlarının satıha yakın harekât icra etme zorunluluğu çoğu zaman sığ sularda gerçekleştiğinden beraberinde deniz tabanı etkilerinin de manevra analizlerine dâhil edilme zorunluluğunu doğurur (Efremov ve Milanov, 2019). Deniz tabanına yaklaşmanın serbest su yüzeyinde olduğu gibi su altı aracının üzerindeki dinamik basınç dağılımı etkileyerek aracı ilave kuvvet ve momentlere maruz bıraktığı ve bu kuvvet ve momentlerin etkisinin kontrol yüzeyleri ve/veya balast sistemi ile dengelenmesinin zorunlu olduğu uzun yıllardır bilinmesine rağmen bu konuda açık literatürde ilk sistematik çalışma Bystron ve Anderson (2000)'un yaptığı deneylerdir. Yazarlar bu deneylerin sonuçlarından cismin deniz tabanının etkisiyle maruz kalacağı düşey yönlü kuvvet ve yunuslama momentinin büyüklüklerinin dip-omurga mesafesindeki değişimin doğrusal bir fonksiyonu olduğu sonucuna ulaşmışlardır.

Su altı aracının etrafındaki dinamik basınç alanının simetrisinin Şekil 19'da gösterildiği gibi deniz tabanının etkisiyle bozulması da serbest su yüzeyinde olduğu gibi Bernoulli İlkesi ile açıklanabilir. Buna göre araç deniz tabanına yaklaştıkça omurga ve deniz tabanı arasında kalan akışkanın miktarı azalacak ve hızı artacaktır. Bu hız artışı ise paralelinde omurga bölgesinde basıncın düşmesine (Venturi etkisi) ve basınç alanının simetrisinin bozularak ilave kuvvet ve momentlerin ortaya çıkmasına sebep olur.

Bu kuvvet ve momentin büyüklüğü (deniz tabanına olan mesafeye bağlı olarak) bazı aşırı durumlarda su altı aracının kontrol yüzeyleri tarafından oluşturulabilen karşıt yönlü etkinin üst sınırı mertebesine ulaşabilmektedirler (Bettle vd., 2010). 


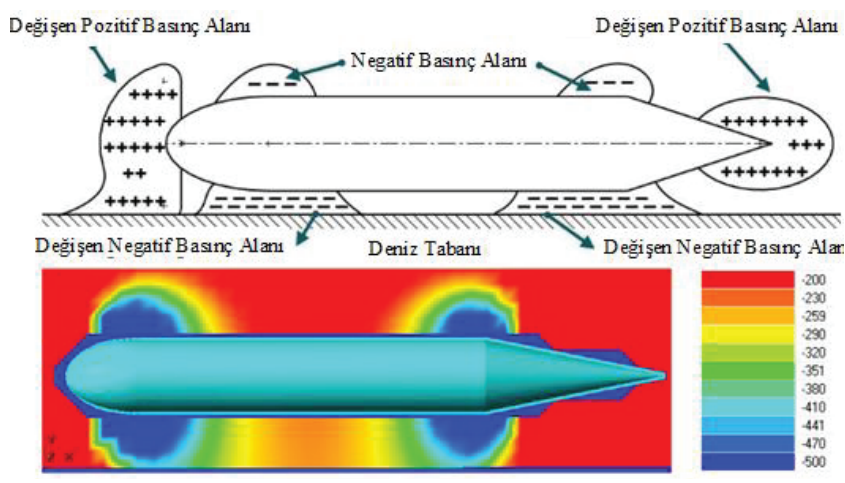

Şekil 19. Deniz tabanı etkisiyle değişen dinamik basınç alanı (Moonesun vd., 2016)

Deniz tabanı ile etkileşimin oluşturduğu kuvvet ve momentler basınç dağılımındaki değişimin sonuçları olduğundan viskoz etkilerden bağımsız oldukları düşünülebilir. Böylece deniz tabanına yakın seyreden bir su altı aracının etrafındaki akışın çözümünde potansiyel teoriye dayalı yöntemlerin doğru sonuç vermesi beklenir (Pétillon vd., 2019). Mackay (2003) bu gerçekten yola çıkarak ve suüstü gemilerinin hızları nedeniyle maruz kaldıkları çökme (squat) olgusu ile benzerlik kurarak su altı araçlarının deniz tabanına yakın seyrederken maruz kaldıkları negatif yönlü kaldırma kuvveti ve çökme miktarını sınır integral yöntemi ile tahmin eden bir yöntem geliştirmiştir.

Sayısal hesaplama altyapısının ve paralelinde viskoz yöntemlerin gelişimi ile ortaya çıkan yeni analiz imkânları bu alanda da araştırmacıların dikkatini çekmiştir. Wu vd. (2005), Bettle vd. (2010), Du vd. (2014), Moonesun vd. (2016) ve Pétillon vd. (2019) çalışmaları ile bu alana öncülük etmiştir.

Wu vd. (2005) RANS denklemlerini kullandığı çalışmalarında Bystron ve Anderson (2000)'un deneysel bulgularını destekleyecek verilere ulaşmış, yine RANS denklemleri ve farklı türbülans modellerini kullanan Du vd. (2014) ve Moonesun vd. (2016) direnç ve kaldırma kuvveti katsayılarının dip-omurga mesafesine bağlı olarak değişimini incelemiş ve bu değişim verisinden deniz tabanı ile etkileşimin başladığı kritik dip-omurga mesafesine ilişkin bir kriter belirlemeye çalışmışlardır. Çalışmalarında çok farklı (takıntılı ve takıntısız) su altı aracı formları kullanan yazarlar e=2 2,5'ten daha büyük mesafeler için ilave direnç bileşeninin, e=5'ten daha büyük mesafeler için ise su altı aracı etrafındaki basınç dağılımındaki asimetrinin (kaldırma kuvveti ve yunuslama momenti) ortadan kalktığı noktasında birleşmişlerdir. Burada "e" su altı aracının deniz tabanına boyutsuz mesafesi olup denklem (11)'deki gibi ifade edilir. Denklem (11)'de yer alan ifadede " $h$ " su altı aracının deniz dibine mesafesini " $D$ " ise çapını temsil etmektedir.

$$
e=\frac{h}{D}
$$

Bu sonuçtan yola çıkarak karakteristik otonom su altı aracı hızlarında $(\leq 5 \mathrm{~m} / \mathrm{s})$ geometriden bağımsız olarak deniz tabanı ile etkileşimin e=5'ten daha küçük mesafeler için söz konusu olacağı söylenebilir. Ayrıca kritik dip-omurga mesafesinin belirlenmesinde kaldırma kuvvetinin daha belirleyici rol oynadığı görülebilmektedir. Bu sonuç ışı̆̆ında Du vd. (2014) düşük dip-omurga mesafelerinde ve doğrusal rotada seyreden bir su altı aracının maruz kalacağı negatif yönlü kaldırma kuvvetinin etkisinin ortadan kaldırılabilmesi için aracın bu derinliklerde küçük bir pozitif ufki dümen açısı ile kullanılmasını tavsiye etmişlerdir.

Her iki çalışmanın yukarıda anlatılan ortak yönlerinin yanında Du vd. (2014) ayrıca incelenen büyüklüklerin ve kaldırma kuvvetinin merkezi ile aracın sephiye merkezinin araç üzerinde farklı yerlerde 
olmasından kaynaklanan yunuslama momentinin su altı aracının hücum açısına göre de değişimine yer vererek düşey düzlemde statik manevra analizleri gerçekleştirmişlerdir. Yazarlar hücum açısı arttıkça su altı aracının akışa karşı gösterdiği yelken alanının artmasının aracın direnç karakteristiklerini olumsuz etkilediğini saptamışlardır. Kaldırma kuvveti ve yunuslama momenti katsayılarının ise artan dip-omurga mesafesi ile ters, artan hücum açısı ile doğru orantılı olduğu yine bu çalışmanın sonuçları arasındadır.

Du vd. (2014) ulaştığı bir diğer ilginç sonuç ise takıntıların varlığı nedeniyle değişimi incelenen büyüklüklerin pozitif ve negatif hücum açılarında farklı değerler almasıdır. Benzer bulgulara Bettle vd. (2010)'de ulaşmış hatta bu farklılıkları sayısal algoritmanın iteratif yakınsama hatalarının belirlenmesi için kullanmışlardır.

Deniz tabanı ile etkileşimin cismin manevra karakteristikleri üzerine yukarıda anlatılan etkilerinin daha iyi anlaşılabilmesi için başka bir yöntem ise bank/duvar etkilerinin analiz edildiği çalışmalar ile mevcut çalışmalar arasındaki benzerliği kullanmaktır. Huang vd. (2020) çekme tankının yan duvar etkilerini model boyutuna kıyasla incelediği çalışmasında $W_{c} / W_{a}=7$ 'den daha büyük boyutsuz yan duvar mesafeleri için $X_{u|u|}$ 'nun 11 'den daha büyük yan duvar mesafeleri için ise $Y_{v}$ ve $Y_{v|v|}$ 'nin sabit kaldığını saptamışlardır. Buna göre çalışma sonuçları Du vd. (2014) ve Moonesun vd. (2016) ile uyum içerisindendir. Burada " $W_{c}$ " çekme tankının genişliğini, " $W_{a}$ " ise model genişliğini ifade etmektedir.

Bu noktaya kadar incelenen çalışmalar deniz tabanı ile etkileşim halindeki su altı araçlarının manevra problemine özellikle düşey düzlemde belirli açılardan ışık tutsa da bu alanda literatürdeki en kapsamlı çalışma yatay ve düşey düzlemdeki statik manevra özelliklerini bir hücum veya sürüklenme açısına sahip gerçek bir denizaltı geometrisini analiz etmek suretiyle Bettle vd. (2010) tarafından yapılmıştır. Deniz tabanı ile etkileşim halinde olan bir su altı aracının maruz kaldığı kuvvet ve momentler aracın, üzerine gelen akışa göre Şekil 20'deki gibi bir hücum açısına sahip olduğu durumlarda Şekil 21'den de gözlemlenebileceği üzere daha fazla değişiklik (artış yönünde) gösterecektir. Her ne kadar Du vd. (2014) hücum açısının etkisini incelemiş olsalar da bu etkinin aracın manevra ve kontrol edilebilirliği açısından sonuçları Bettle vd. (2010) tarafından ortaya konulmuştur.

Buna göre yazarlar negatif yönlü (baş aşağı) hücum açılarında ve incelenen en küçük dip-omurga mesafeleri için deniz tabanı etkisiyle oluşan aşağı yönlü kuvvetin büyüklüğünün, baş ufki dümenlerin $20^{\circ}$ dümen açısı ile yarattıkları düşey doğrultulu yukarı yönlü kuvvet ile aynı mertebede olduğunu göstermişlerdir. Dip omurga mesafesinin daha da azalması veya negatif yönlü hücum açısının artması oluşan aşağı yönlü kaldırma kuvvetinin baş ufki dümenler ile karşılanamaması ve neticede su altı aracının dibe çarpması ile sonuçlanabilir. Negatif hücum açılarında su altı aracının baş tarafı ile deniz tabanı arasındaki mesafe azalarak bu bölgede - nozul etkisi nedeniyle- hız artışına ve dolayısı ile alçak basınç alanının oluşmasına neden olacaktır. Aracın kıç tarafında ise aksi yönde bir etki yüksek basınç alanı oluşumuna sebep olur.

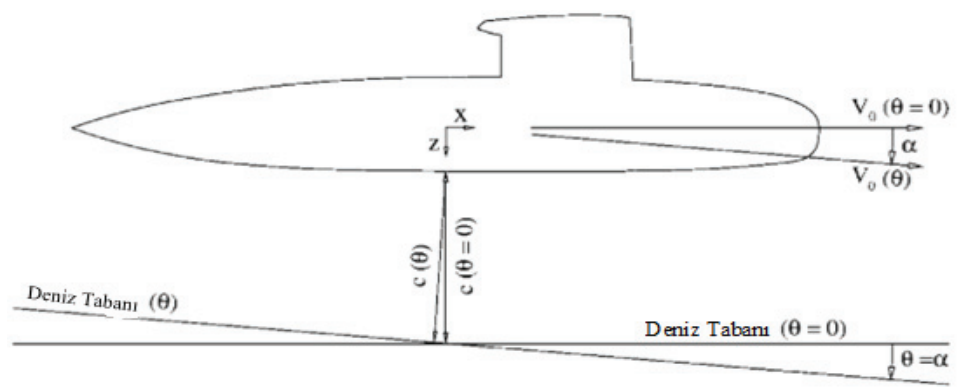

Şekil 20. Deniz Tabanına Yakın Su altı Aracının Şematik Gösterimi (Bettle vd., 2010) 
Bu durum su altı aracının baş tarafında dip ile etkileşimin artmasına ve oluşan aşağı yönlü kuvvetin büyüklüğünün artarak baş tarafın daha fazla dibe çekilmesi ile sonuçlanır ve negatif hücum açısının artmasına sebep olur. Başlangıçta pozitif hücum açısına sahip bir su altı aracı için ise tam tersi bir durum söz konusudur. Hücum açısı kaçınılmaz olarak pozitif yönde daha da artar. Sonuç olarak küçük bir hücum açısı pertürbasyonuna (negatif veya pozitif) maruz kalan deniz tabanı ile etkileşim halindeki su altı aracı herhangi bir kontrol sistemi gidisi olmaksızın bu pertürbasyonu sönümleyemez ve giderek daha büyük yunuslama momentlerinin etkisi altında kalır. Bu bakımdan deniz tabanı ile etkileşim halindeki su altı araçları yunuslama yönündeki pertürbasyonlara karşı düşey düzlemde stabil değildirler ve deniz tabanı ile mesafelerini korumak için kontrol yüzeylerinin kuvvet girdisine ihtiyaç duyarlar.
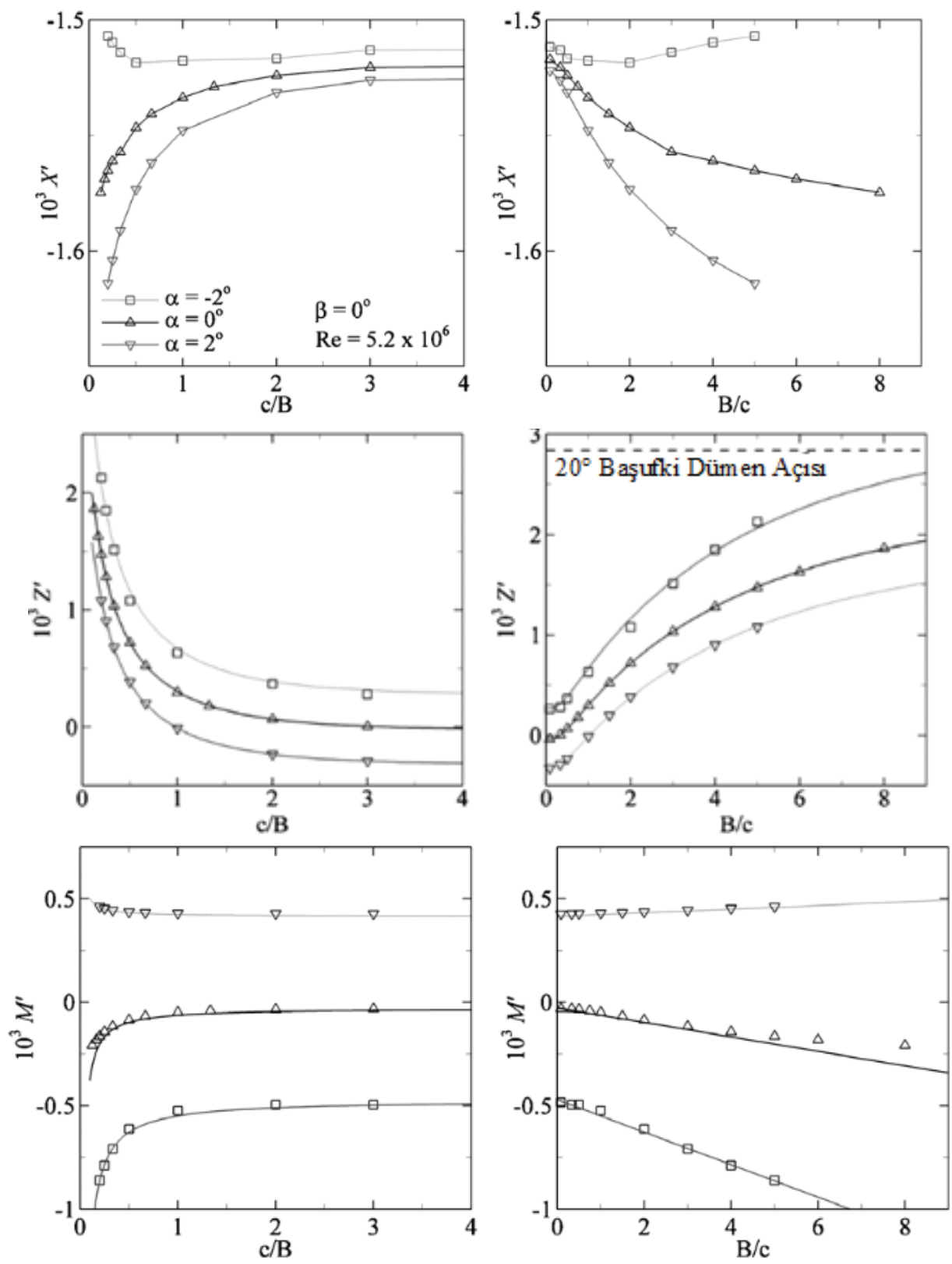

Şekil 21. Düşey düzlemde kuvvet/momentlerin farklı $\alpha$ açıları için c/B ile değişimi (Bettle vd., 2010).

Bettle vd. (2010) çalışmasının bir diğer inceleme konusu da yatay düzlemde statik sürüklenmenin deniz tabanı ile etkileşimde olan aracın yatay ve düşey düzlem manevra karakteristiklerine olan etkilerdir. Buna göre eksenel yönlü kuvvetin Şekil 22'den de görülebileceği üzere küçük sürüklenme açılarında 
ISSN: 1300-1973, e-ISSN: 2651-530X, Dergi ana sayfası: http://www.gmoshipmar.org/

$\left(\beta \leq 5^{\circ}\right)$ azalan dip-omurga mesafesi ile yavaşça arttığı ancak sürüklenme açısının daha büyük değerleri için bu artışın daha hızlı olduğu yine bu çalışmanın sonuçları arasındadır.

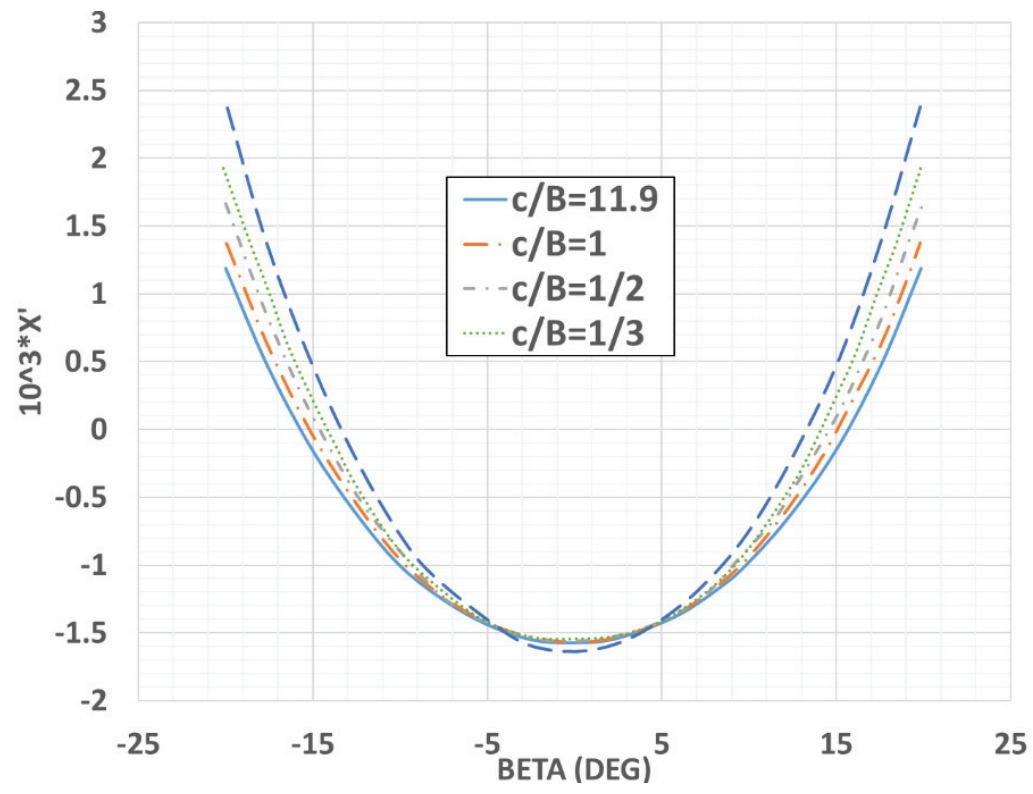

Şekil 22. Eksenel yönlü kuvvetin değişik c/B değerleri için $\beta^{\prime}$ ya bağlı değişimi (Bettle vd., 2010)

Hareketle (statik sürüklenme) aynı düzlemde olan yanal öteleme (sway) kuvveti "Y" ile savrulma (yaw) "N" ve ayrıca yalpa (roll) "K" momentlerinin sürüklenme açısından bağımsız olarak azalan dip-omurga mesafesi ile artma eğiliminde oldukları Şekil 23'ten gözlemlenebilir.
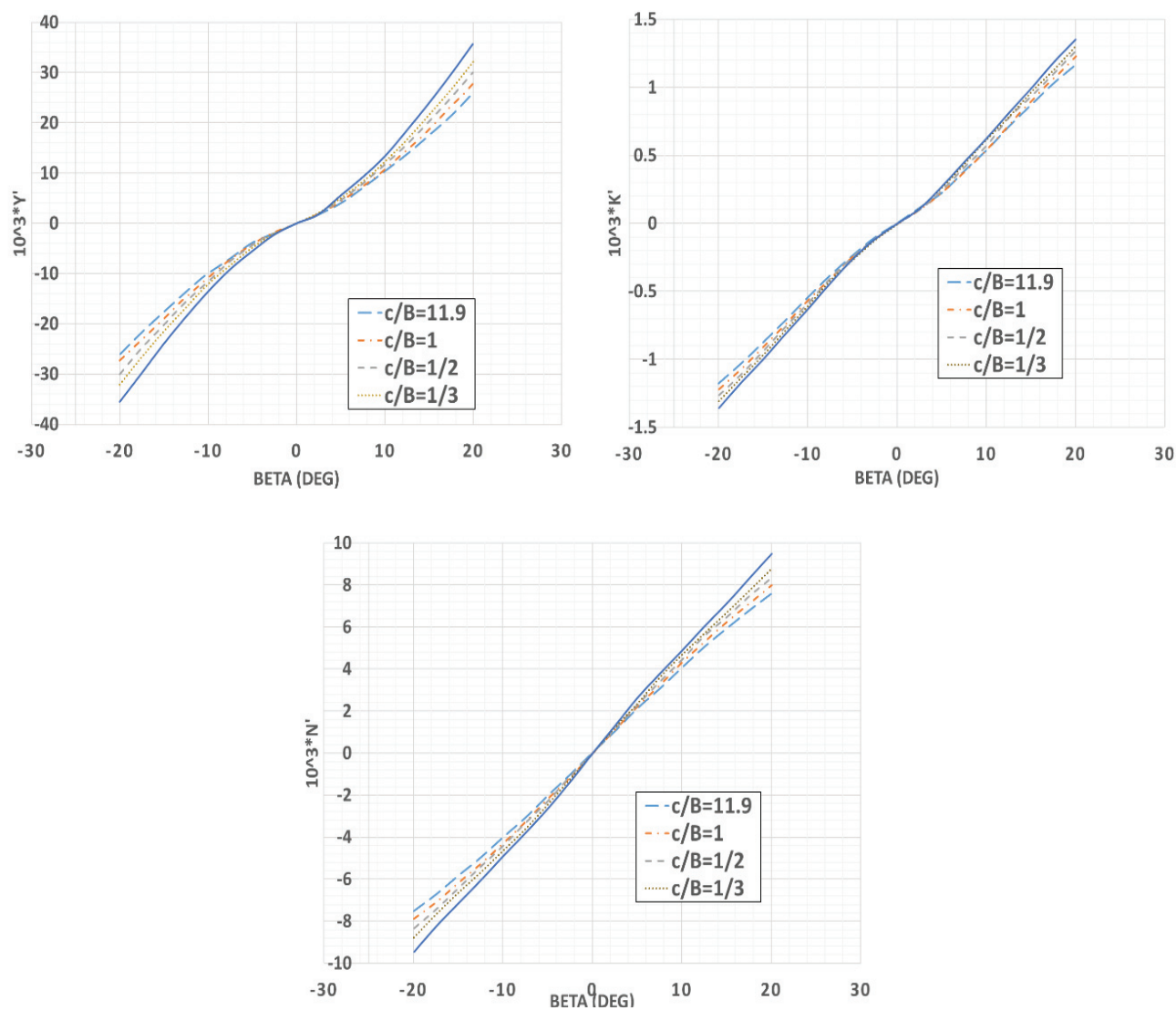

Şekil 23. Yatay düzlemde kuvvet/momentlerin değişik c/B için $\beta^{\prime}$ ya bağlı değişimi (Bettle vd., 2010) 
Statik sürüklenme açısının varlığı sadece kendisi ile aynı düzlemdeki (yatay) kuvvet ve momentleri değil aynı zamanda yelkenin rüzgaraltı tarafında oluşan girdaplııı nedeniyle düzlem dışı (out-of-plane) kuvvet ve momentleri de etkiler. Çapraz akışla etkileşime girerek su altı aracının güverte ve omurgası arasında bir dinamik basınç farkı oluşmasına sebep olan söz konusu rüzgaraltı girdapsı yapılar, güverte düzlemindeki basıncın omurga düzlemine göre daha büyük olmasına neden olarak düşey doğrultuda aşağı yönlü bir kuvvetin oluşmasına (Magnus etkisi) sebep olurlar. Magnus etkisinin şiddeti dip-omurga mesafesinin azalan bir fonksiyonudur. Ancak dip-omurga mesafesinin bu çalışma kapsamında incelenen en büyük değeri için bile bahse konu girdap etkileşimleri sebebiyle önemli ölçüde bir düşey yönlü kuvvetin oluşması kaçınılmazdır.

Girdap etkileşimleri nedeniyle oluşan aşağı yönlü kuvvet aracın yelkeninin izler kenarı ile kıç bölgesi arasında oluşacağından, kuvvetin merkezinin de aracın sephiye merkezinin kıç tarafında yer alması gerekir. Her iki kuvvet merkezi arasındaki mesafe (moment kolu) aracın ayrıca bir yunuslama momentine maruz kalmasına neden olur. Su altı aracının dönüş anında oluşan orta büyüklükte $\left(5^{\circ}-15^{\circ}\right)$ sürüklenme açıları ile dibe yakınlığın kombinasyonunun Magnus etkisi sebebiyle oluşan aşağı yönlü kuvvetin baş ufki dümenler ile ( $20^{\circ}$ dümen açısı kullanılarak) karşılanamayacak büyüklüğe ulaşmasına sebep olabilecektir. Bu durum, oluşum sebepleri yukarıda ayrıntılı olarak açıklanan düşey doğrultulu kuvvet ve yunuslama momentinin su altı aracının kontrol ve manevra edilebilirliği üzerine ne derece etkili olduğunu kanıtlamaktadır. Dolayısı ile operasyonel ihtiyaçlar sebebiyle sığ sularda kullanılacak ve sürekli deniz tabanı ile etkileşim halinde bulunacak su altı araçlarının kontrol yüzeylerinin boyut, mevki ve geometrik tasarımlarında aracın Magnus etkisi nedeniyle maruz kalacağı azami momentin karşılanabiliyor olması bir tasarım kriteri olmalıdır.

Nihai olarak deniz tabanı ile etkileşim halinde olan su altı araçlarının manevra problemini konu alan literatürün hâlihazırda kapsamadığı ancak bu problemin bütünüyle kavranabilmesi için araştırılması gereken başlıklar yine Bettle vd. (2010) tarafından özetlenmiştir. Buna göre deniz tabanının varlığının; rotasyonel manevra katsayılarına, sürüklenme ve hücum açısı kombinasyonlarına, kontrol yüzeylerinin yarattığı kuvvetlere ve emercensi satıh manevrası gibi ani gelişen (zamana bağlı) manevralara etkilerinin de analiz edilmesi bu konudaki literatüre tamamlayıcı yönde katkı sunacaktır.

\section{Sınır Etkilerin Manevra Modelinde Temsil Edilmesi}

Su altı araçları işlevlerini yerine getirirken her durumda emniyetli seyir yapabilmelidirler. Bunun için gerçekleştirdikleri manevra yörüngelerinin önceden hesaplanabilmesi ve bu yörünge verisine istinaden araca özgü emniyetli seyir zarfının (Maneuvering Limitation Diagram-MLD) oluşturulması gereklidir. Derin dalmış durumda bu zarf aracın mukavim teknesinin hidrostatik basınç altında parçalanacağı derinliğin altına inmesine sebep olacak manevraların tespitinden ibaret iken, sınır etkileri söz konusu olduğunda aracın serbest su yüzeyini yarmasının ve deniz dibine çarpmasının önlenmesi gibi sınırlamaları da içermelidir.

Su altı aracının manevra hesaplamalarının yapılarak emniyetli seyir zarfının oluşturulabilmesi için bir manevra simülasyon modeline intiyaç vardır (Renilson, 2015). Ancak bu modelde akışkan sınırı etkilerinin de doğru temsil edilmesi gereklidir (Polis vd., 2013b). Serbest su yüzeyi ve deniz dibinin su altı aracı üzerine yatay ve düşey düzlemlerde fiziksel etkileri ile bu etkilerin nedenleri/sonuçları incelendikten sonra anılan etkilerin hareketi kontrol eden denklemlerde nasıl temsil edileceği sorusu ortaya çıkmaktadır. 
Klasik manevra modelleri, su altı aracının hareketlerini açıklamak için araca etkiyen kuvvet ve momentleri bu büyüklüklerin değişik kinematik parametrelere (doğrusal/açısal hız/ivme vb.) göre değişimini gösteren hidrodinamik katsayılar cinsinden hesaplamalara yansıtır.

Sınır etkilerinin söz konusu olduğu durumlarda araca etkiyen kuvvet ve momentler kinematik parametrelerin yanında derinliğin, dip-omurga mesafesinin ve Froude sayısının da bir fonksiyonudurlar ve bu parametrelerdeki değişimin kuvvet/momentler üzerine etkilerinin de kullanılan manevra modelinde matematiksel olarak temsil edilmesi gerekir. Akışkan sınır etkilerinin matematiksel olarak manevra hesaplarına yansıtılabilmesi için;

- Farklı derinlikler için katsayıların elde edilerek literatürde mevcut manevra modellerinde kullanımı,

- Hidrodinamik kuvvet ve momentlerin sadece kinematik parametrelerin değil aynı zamanda derinliğin, dip-omurga mesafesinin ve Froude sayısının da fonksiyonu olduğu yeni bir matematiksel modelin geliştirilmesi,

seçeneklerinden birisi tercih edilmelidir (Amiri vd., 2019).

Açık literatürde henüz serbest su yüzeyi etkilerini de kapsayan genel geçer bir manevra modeli bulunmamakla beraber farklı derinliklerde yapılan analizler vasıtası ile hidrodinamik katsayı-derinlik korelasyonunu saptamayı hedefleyen çalışmalar mevcuttur.

Polis vd., (2013b) düşey düzlemde serbest su yüzeyi etkilerini Gertler ve Hagen (1967)'ın manevra modeline yansıtabilmek için ilerleme ve dalıp çıkma kuvveti ( $X^{\prime}$ ve $Z^{\prime}$ ) ile yunuslama momenti ( $\left.M^{\prime}\right)$ katsayılarını (boyutsuz) su altı aracının farklı dalma derinlikleri için hesaplamış ve böylece derin dalmış durumdan sapmayı da katsayı formunda türetmişlerdir. Bu formülasyona göre derinliğin ve Froude sayısının fonksiyonu olan nihai katsayılar $\left(\mathrm{X}_{*}^{\prime}\left(\mathrm{Fr}, \mathrm{H}^{*}\right), \mathrm{Z}_{*}^{\prime}\left(\mathrm{Fr}, \mathrm{H}^{*}\right)\right.$ ve $\left.\mathrm{M}_{*}^{\prime}\left(\mathrm{Fr}, \mathrm{H}^{*}\right)\right)$ matematiksel olarak derin su katsayıları $\left(\mathrm{X}_{* \mathrm{ds}}^{\prime}, \mathrm{Z}_{* \mathrm{ds}}^{\prime}\right.$ ve $\left.\mathrm{M}_{* \mathrm{ds}}^{\prime}\right)$ ile sapma katsayılarının $\left(\Delta \mathrm{X}_{*}^{\prime}\left(\mathrm{Fr}, \mathrm{H}^{*}\right), \Delta \mathrm{Z}_{*}^{\prime}\left(\mathrm{Fr}, \mathrm{H}^{*}\right)\right.$ ve $\Delta \mathrm{M}_{*}^{\prime}\left(\mathrm{Fr}, \mathrm{H}^{*}\right)$ ) süperpozisyonu olarak aşağıdaki şekilde (denklem (12), (13) ve (14) ifade edilebilirler.

$$
\begin{gathered}
X_{*}^{\prime}\left(F r, H^{*}\right)=X_{* d s}^{\prime}+\Delta X_{*}^{\prime}\left(F r, H^{*}\right) \\
Z_{*}^{\prime}\left(F r, H^{*}\right)=Z_{* d s}^{\prime}+\Delta Z_{*}^{\prime}\left(F r, H^{*}\right) \\
M_{*}^{\prime}\left(F r, H^{*}\right)=M_{* d s}^{\prime}+\Delta M_{*}^{\prime}\left(F r, H^{*}\right)
\end{gathered}
$$

Sapma katsayılarının yukarıdaki formülasyonda kullanılabilmesi için derin su katsayıları ile kinematik parametreler arasında olduğu gibi Froude sayısı ve derinlikle olan korelasyonlarının matematiksel olarak bilinmesi gerekir. Bu matematiksel ifade HAD veya deney sonuçlarına eğri uydurma yöntemi ile seçilen sürekli bir fonksiyon olabileceği gibi parçalı bir fonksiyon da olabilir (Polis vd., 2013b).

Serbest su yüzeyinin varlığı nedeniyle hidrodinamik katsayılardaki değişimin matematiksel formülasyonu belirlendikten sonra manevra probleminde olası basitleştirmelerin yapılabilmesi için hangi katsayıların ne derece etkilendiğinin ve sapma miktarı ihmal edilebilecek düzeyde olan spesifik katsayıların belirlenmesi gereklidir. Su altı aracı etrafındaki akışın derin dalmış durum ile satıha yakın durum arasındaki en temel farkı düşey düzlemde akışın simetrisinin bozulması olduğundan, Broglia vd. (2007), Polis vd. (2013b) ve Renilson (2015) tarafından yalnızca düşey düzlem serbestlik derecelerine ilişkin katsayıların denklem (12), (13) ve (14) ile verilen ifadeler kullanılarak hesaplanmasının yeterli 
olacağı öne sürülmüştür. Ancak Bölüm 7'de anlatıldığı gibi yakın zamanda yapılan yatay düzlem dinamik stabilite analizleri (Amiri vd., 2019) bu varsayımın bütünüyle doğru olmadığını ve derin dalmış duruma kıyasla yatay düzlemde stabilitesi artan su altı aracının hareketlerinin derin dalmış durum için türetilen katsayılar ile tatmin edici bir şekilde açıklanamayacağını göstermiştir. Manevra modelinin doğru yörünge tahmini yapabilmesi için hidrodinamik katsayılar derinliğin ve Froude sayısının bir fonksiyonu olacak şekilde hesaplanmalı veya hareket denklemleri akışkan sınır etkilerini de içerecek şekilde genelleştirilmelidir

\section{Serbest Su Yüzeyinin Varlığının Problemin Sayısal ve Deneysel Boyutuna Etkileri}

Serbest su yüzeyinin su altı aracının maruz kaldığı kuvvet ve momentlere ve dolayısı ile bu büyüklüklerin çeşitli parametrelere göre değişimini gösteren hidrodinamik katsayılara etkilerinin yanında kuvvet ve momentlerin ölçüm/hesaplama yöntemleri üzerine de bir takım etkilerinin olması kaçınılmazdır.

Kullanılan nümerik algoritmada derin dalmış duruma göre ilave iki sınır koşulunun daha (dinamik ve kinematik yüzey sınır koşulları) sağlanması zorunluluğunun getirdiği karmaşıklı̆ın yanında rijit olmayan sınırın yerinin önceden bilinememesi bu sınır koşullarının probleme empoze edilebilmesi için iteratif bir çözüm algoritmasını ve ilave hesaplama yükünün karşılanmasını zorunlu kılmaktadır.

Ayrıca su altı aracının dinamik basınç alanı ile etkileşimin sonucunda deforme olan serbest su yüzeyinin dalga yapısının araca etkiyen kuvvet ve momentlerin doğru tahmin edilebilmesi için yüksek çözünürlükle (yoğun bir ağ yapısı kullanılarak) saptanması gerekliliği yine ilave hesaplama yükü getiren bir diğer etkendir.

Serbest su yüzeyinin düşey düzlemde problem simetrisini bozmasının bir diğer sonucu da, statik sürüklenme simülasyonlarında yalnızca akışın geliş açısının değiştirilerek aynı ağın aracın farklı açısal oryantasyonlarının analizinde kullanılabildiği derin dalmış durumun aksine, her bir hesaplama senaryosu için farklı bir ağa intiyaç duyulmasıdır. Neticede serbest su yüzeyinin etkisi altında ağ oluşturmak daha fazla hesaplama kaynağının kullanımı anlamına gelmektedir.

Sayısal analizlerin sonlu bir hacimde (kontrol hacmi) yapılması zorunluluğu su altı aracının etrafındaki akışkan alanının her iki yanda, akış ve akışın tersi yönlerde yapay olarak sınırlandırılması sonucunu doğurmaktadır. Su altı aracının etkisiyle deforme olarak bir Kelvin iz paterni oluşturan serbest su yüzeyinin ise bu yapay sınırlardan yansıyan dalgalara sebep olmaması gereklidir. Bunun için aracın Kelvin izini oluşturan dalga sisteminin hesaplama bölgesinin dışında yapay olarak sönümlenmesi ve problemi daha karmaşık hale getirecek bir "sayısal sönümleme bölgesi"nin ve algoritmasının probleme dâhil edilmesi gereklidir.

Bir diğer sayısal problem ise mevcut yöntemlerin serbest su yüzeyinin su altı aracı tarafından yarılması gereken durumlarda (büyük açıların kullanıldığı sürüklenme deneyleri, direk sürmeyi gerektiren operasyonlar vb.) karşılaştıkları sayısal algoritmanın yakınsama problemleri ve doğrusallaştırılmış serbest su yüzeyi kabulünün geçerliliğini kaybetmesi gibi ilave güçlüklerdir (Griffin, 2002). Serbest su yüzeyinin doğrusallaştırılamaması viskoz yöntemler ile birlikte VOF ve ALE gibi serbest su yüzeyi yakalama algoritmalarının kullanımı zorunluluğunu doğuracaktır.

Deneysel yöntemler açısından araştırmacıların karşılaştığı başlıca zorluk ise birbirinden farklı ölçüm yöntemlerinin kullanımını gerektiren birçok farklı parametrenin bir arada ve eş zamanlı ölçüm zorunluluğudur. Lokal (basınç), global (kuvvet) ölçümler ile serbest su yüzeyi dalga profillerinin tespiti eş zamanlı olarak yapılmalıdır. 
Bir destek mekanizması ile deney düzeneğine bağlanan su altı aracı için yukarıda ifade edilen ölçüm zorluğuna ek olarak destek mekanizmasının serbest su yüzeyi ve model ile girdiği etkileşimlerin ölçüm sonuçlarını etkilemesi ve bu etkilerin sonuçlardan arındırılması diğer bir problem kaynağıdır. Amiri vd. (2018); Dawson (2014) (serbest su yüzeyine yakın) ve Liu ve Huang (1998) (derin dalmış) gerçekleştirdiği model deney senaryolarından bazılarını destek mekanizmasının sonuçlar üzerine etkisini görmek için sayısal olarak modellediği (destek mekanizması ile birlikte) çalışmasında çubuk (strut) ve iğne (sting) tipi desteklerin incelenen analiz koşullarında ve kullanılan geometri için direnç karakteristiklerini değiştirdiği ancak iğne tipi desteğin düşey düzlemdeki kuvvet ve momentler üzerindeki etkisinin ihmal edilebilir düzeyde olduğunu raporlamıştır. Bu durum aynı zamanda Bölüm 2'de öne sürülen baskın dalga sistemi olgusuna da kanıt niteliği taşımaktadır. Destek mekanizmasının varlığı nedeniyle önemli ölçüde değişen modelin kıç geometrisi düşey düzlemde kuvvet ve momentler üzerinde ancak marjinal bir değişikliğe sebep olmuştur. Her ne kadar Amiri vd. (2018)'nin ulaştığı sonuçlar deneysel verilerin destek mekanizmasının varlığından etkilenmediği yolunda kanıt sunsa da bu gösterimin ve kabulün yapılabilmesi ancak HAD analizleri ile mümkün olduğundan pratik ve ekonomik bir uygulama değildir.

Bir diğer deney düzeneği alternatifi de serbest hareketli (free running) modellerin kullanımı olup, bu alternatifin de kendi içerisinde serbest su yüzeyinin varlığı sebebiyle karşılaştığı bir takım problemler mevcuttur. Düşey düzlemde serbest su yüzeyiyle etkileşim nedeniyle modelin maruz kaldığı kuvvet ve momentler modelin açısal oryantasyonunun ve serbest su yüzeyine mesafesinin korunması için bir otopilot algoritması ile birlikte kontrol yüzeylerinin de sürekli kullanımını zaruri hale getirecektir. Bu durum deforme olmuş kontrol yüzeyleri ile yeni etkileşimlerin ve zamana bağlı etkilerin ortaya çıkmasına sebep olacaktır.

\section{Sonuçlar}

Bu çalışma kapsamında; akışkan sınırlarının su altı araçlarının manevra karakteristiklerine etkileri konusundaki literatür bu alandaki öncü çalışmalardan başlayarak taranmış ve anılan etkilere ilişkin bulguların bir sınıflandırılması yapılmıştır. Böylece bağımsız ve dağınık durumdaki çalışmalardan oluşan literatürün incelenen başlıklar altında ilişkili yönleri bir araya getirilerek genel bir değerlendirme yapılmıştır. Bu değerlendirmeden elde edilen çıkarımlar kısaca şu şekilde özetlenebilir:

- Su altı aracının akışkan sınırlarından etkilendiği ve bu sınırları etkileyebildiği kritik bir mesafe mevcuttur. Araç bu mesafenin dışında derin dalmış durumda kabul edilir ve manevra karakteristikleri akışkan sınırlarının varlığından etkilenmez. (Bölüm 2)

- Kritik mesafeden daha küçük mesafelerde Bernoulli illkesinin bir sonucu olarak aracın etrafındaki dinamik basınç alanının düşey yönde simetrisi bozulur. Bozulan basınç alanı ise serbest su yüzeyini deforme eder. Bu karşılıklı etkileşim aracın düşey yönde bir kaldırma kuvveti ve yunuslama momentine maruz kalmasına ve neticede manevra özelliklerinin değişmesine neden olur. (Bölüm 3)

- Aracın maruz kaldığı kuvvet ve momentler serbest su yüzeyiyle mesafenin ve Froude sayısının bir fonksiyonudurlar. Anılan büyüklüklerin Froude sayısı ile ilişkisi $\mathrm{Fr}=0.5$ 'e kadar periyodiktir. (Bölüm 2)

- Su altı aracının akışkan sınırlarına yaklaşması aracın hızına ve sınıra olan mesafesine bağlı olarak düşey düzlemde kontrol yüzeyleri tarafından karşılanamayacak büyüklükte kuvvet ve 
momentlerin oluşmasına ve neticede aracın serbest su yüzeyini yararak tespit edilmesine veya deniz tabanına çarpmasına neden olabilir. (Bölüm 6 ve 11)

- Kuvvet ve momentlerin periyodik davranışı, aracın serbest su yüzeyinde yarattığı deformasyonu (Kelvin izinin) oluşturan dalga sistemlerinin birbirleri ile etkileşimi ile açıklanabilir. Bu etkileşim de Froude sayısının bir fonksiyonudur. (Bölüm 2)

- Bu etkileşimlerden bir tanesi diğerlerine göre daha baskın olup satıha yakın bir su altı aracının hidrodinamik davranışı baş ve kıç omuzluk dalga sistemlerinin etkileşimi ile açıklanabilir. Buna göre baş dalgasının dalga çukurunun aracın kıç omuzluğundaki düşük basınç alanı ile örtüşme oranı araca etkiyen kuvvetlerin şiddetini belirleyecektir. (Bölüm 6)

- Su altı aracının yatay düzlemde dinamik stabilitesi derinliğin azalan bir fonksiyonudur. Buna göre serbest su yüzeyine yaklaştıkça aracın stabilitesi artar. Bu durum " $r$ " ve " $v$ " hızları nedeniyle oluşan bileşke $\mathrm{N}$ momentinin satıha yaklaştıkça azalması ile açıklanabilir. (Bölüm 7)

- Çapraz akış ayrıımasının neden olduğu girdaplarla etkileşim, serbest su yüzeyinin neden olduğu düşey düzlem kuvvet ve momentlerini de değişikliğe uğratacak düzlem dışı etkilere neden olur. Düzlem dışı etkiler nedeniyle oluşan aşağı yönlü $Z$ kuvveti orta büyüklükteki sürüklenme açılarında $\left(\beta \sim 10^{\circ}\right)$ ve karakteristik su altı aracı hızlarında serbest su yüzeyinin varlığı nedeniyle oluşan yukarı yönlü $Z$ kuvveti ile aynı mertebeye ulaşır. Daha büyük sürüklenme açılarında bileşke $Z$ kuvvetinin işareti düzlem dışı etkiler sebebiyle yön değiştirir ve $M$ momentinin büyüklüğü azalır. (Bölüm 8)

- Takıntıların serbest su yüzeyine etkileri konusunda literatürde birbirleri ile örtüşmeyen sonuçlar olsa da serbest su yüzeyinin varlığı dümen verimini olumsuz etkilemektedir. Bu sonuç serbest su yüzeyine yaklaştıkça yatay düzlem stabilitesindeki artış ile birlikte değerlendirildiğinde aracın manevra edilebilirliğinin ciddi şekilde azalacağı sonucuna varılabilir. (Bölüm 9)

- Su altı araçlarının serbest su yüzeyine yakın gerçekleştirdikleri operasyonlardaki tipik mesafelerde (periskop derinliği vb.) sevk sistemi parametreleri serbest su yüzeyinin varlı̆ı̆ıdan etkilenmezler. Buna göre sevk sisteminin kendisine özgü bir mesafe kriteri olduğu (literatürde genel kabul suüstü gemileri için ITTC tarafından önerilen pervane çapının 1.5 katı) iddia edilebilir. Bu mesafeden daha küçük mesafelerde ise tekne-pervane etkileşim parametreleri ( $t$ ve w) azalır. (Bölüm 10)

- Deniz tabanına yaklaştıkça araç negatif yönlü bir kaldırma kuvvetine ve yunuslama momentine maruz kalır. (Bölüm 11)

- Düşey düzlemde statik sürüklenme durumunda ise artan hücum açısı söz konusu bu büyüklüklerin de artmasına neden olur. Ayrıca yine Bernoulli ilkesi sebebiyle aracın maruz kaldığı kuvvet ve momentler hücum açının daha da artmasına sebep olurlar. Kontrol sistemi girdisi olmaksızın bu durum aracın dibe çarpması ile sonuçlanacağından deniz tabanı ile etkileşim halindeki su altı araçlarının yunuslama yönündeki pertürbasyonlara karşı stabil olmadıkları söylenebilir. (Bölüm 11)

- Yatay düzlemde statik sürüklenme manevrası yapan deniz tabanı ile etkileşim halindeki su altı araçlarının maruz kaldığı kuvvet ve momentler ise sürüklenme açısından bağımsız olarak azalan dip-omurga mesafesi ile artar. (Bölüm 11) 
- Serbest su yüzeyiyle etkileşim durumunda olduğu gibi yatay düzlemde statik sürüklenme manevrası; çapraz akış ayrılmasının sebep olduğu girdaplar ile yelkenin iz bölgesinde oluşan girdaplı akışın etkileşimi sebebiyle düzlem dışı kuvvetlerin de ortaya çıkmasına sebep olur. Bu etkileşim güverte düzlemindeki basıncın omurga düzlemine göre artmasına ve neticede Magnus etkisi sebebiyle aşağı yönlü bir kuvvetin ortaya çıkmasına sebep olur. Magnus etkisi dönüş manevrası esnasında aracın dibe çarpmasına neden olabilir. (Bölüm 11)

- Akışkan sınırlarına yakın manevra yapan bir su altı aracının yörüngesi derin dalmış durum için saptanan hidrodinamik katsayılar ile doğru olarak tahmin edilemez. Manevra modelinin doğru yörünge tahmini yapabilmesi için hidrodinamik katsayılar derinliğin ve Froude sayısının bir fonksiyonu olacak şekilde hesaplanmalı veya hareket denklemleri akışkan sınır etkilerini de içerecek şekilde genelleştirilmelidir. (Bölüm 12)

- Sınır etkileri altındaki bir su altı aracının manevra analizi gerek nümerik sayısal gerekse de deneysel açıdan ilave zorluklara sebep olacaktır. (Bölüm 13)

Gelecekte akademik gayretlerin yönlendirilmesi gereken başlıca alanlar ise şunlardır;

- Akışkan sınırlarının rotasyonel hidrodinamik katsayılar üzerine olan etkilerinin incelenmesi,

- Sınır etkileri altında sürüklenme ve hücum açısı kombinasyonlarının analizi,

- Zamana bağıı manevraların özellikle satıha çıkma manevrasının analizi, aracın dinamik stabilite özelliklerinin serbest su yüzeyine yaklaştıkça zamana bağlı değişimi,

- Kontrol yüzeylerin yarattığı kuvvetlerin sınır etkileri altında gerçekçi olarak analiz edilmesi,

- Hareket denklemlerinin sınır etkilerini de kapsayacak derinlik ve Froude sayısının da fonksiyonu olacak şekilde yeniden türetilmesi veya hidrodinamik katsayıların derin dalmış durumdan farkını gösteren sapma katsayılarının tamamının türetilmesi,

- Sayısal çalışmalarda ağırlıklı olarak kullanılan RANS yaklaşımında daha gelişmiş türbülans modellerinin veya daha gelişmiş sayısal yaklaşımların (RSM, DES, LES, vb.) kullanımı,

- Dalmış durumda bir sualtı aracının yoğunluk tabakası yakınında maruz kalacağı ilave kuvvet ve momentlerin araştırılması.

\section{Referanslar}

Amiri, M. M., Esperança, P. T., Vitola, M. A., \& Sphaier, S. H. (2018). How Does the Free Surface Affect the Hydrodynamics of a Shallowly Submerged Submarine. Applied Ocean Research, 76(April), 34-50. https://doi.org/10.1016/j.apor.2018.04.008

Amiri, M. M., Esperança, P. T., Vitola, M. A., \& Sphaier, S. H. (2019). An initial evaluation of the free surface effect on the maneuverability of underwater vehicles. Ocean Engineering, 196(December 2019), 106851. https://doi.org/10.1016/j.oceaneng.2019.106851

Amiri, M. M., Sphaier, S. H., Vitola, M. A., \& Esperança, P. T. (2018). URANS Investigation of the Interaction Between the Free Surface and a Shallowly Submerged Underwater Vehicle at Steady Drift. Applied Ocean Research, 84(June 2018), 192-205. https://doi.org/10.1016/j.apor.2019.01.012 
Bettle, M., Toxopeus, S. L., \& Gerber, A. (2010). Calculation of Bottom Clearance Effects on Walrus Submarine Hydrodynamics. International Shipbuilding Progress, 57(3-4), 101-125.

Broglia, R., Di Mascio, A., \& Muscari, R. (2007). Numerical study of confined water effects on a selfpropelled submarine in steady manoeuvres. Proceedings of the International Offshore and Polar Engineering Conference, 17(2), 443-450.

Bystron, L., \& Anderson, R. (2000). The submarine underwater maneuvering. Submarine Technology research and development. In The 5th International Conference on Submarines Selection (pp. 132143). China Ship Scientific Research Center.

Carrica, P. M., Kim, Y., \& Martin, J. E. (2019). Near-Surface Self Propulsion of a Generic Submarine in Calm Water and Waves. Ocean Engineering, 183(May), 87-105. https://doi.org/10.1016/j.oceaneng. 2019.04.082

Conway, A. S. T., Valentinis, F., \& Seil, G. (2018). Characterisation of Suction Effects on a Submarine Body Operating Near the Free Surface. Proceedings of the 21st Australasian Fluid Mechanics Conference (10-13 December 2018), Adelaide, Australia. Retrieved from https://people.eng.unimelb. edu.au/imarusic/proceedings/21/Contribution_766_final.pdf

Crook, T. P. (1994). An Initial Assessment of Free Surface Effects on Submerged Bodies (Master's thesis). Naval Postgraduate School, Monterey, CA. Retrieved from http://hdl.handle.net/10945/42971

Dawson, D.W., "A Practical Computer Method for Solving Ship-Wave Problems", Proc. 2nd Int. Conf. Nu- merical Ship Hydrodynamics, Office of Naval Research, USA, 30-38, 1977.

Dawson, E. (2014). An Investigation into the Effects of Submergence Depth, Speed and Hull Length-toDiameter Ratio on the Near- Surface Operation of Conventional Submarines (Master's thesis). University of Tasmania, Australia. Retrieved from https://eprints.utas.edu.au/22368/

Doctors, L. J., \& Beck, R. F. (1987). Numerical Aspects Of The Neumann-Kelvin Problem. Journal of Ship Research, 31(01), 1-13.

Doğrul, A. (2019). Hydrodynamic Investigation of a Submarine Moving Under Free Surface. Journal of ETA Maritime Science, 7(3), 212-227.

Du, X. xu, Wang, H., Hao, C. zhi, \& Li, X. liang. (2014). Analysis of Hydrodynamic Characteristics of Unmanned Underwater Vehicle Moving Close to the Sea Bottom. Defence Technology, 10(1), 76-81. https://doi.org/10.1016/j.dt.2014.01.007

Dubbioso, G., Broglia, R., \& Zaghi, S. (2017). CFD Analysis of Turning Abilities of a Submarine Model. Ocean Engineering, 129(October), 459-479. https://doi.org/10.1016/j.oceaneng.2016.10.046

Efremov, D. V., \& Milanov, E. M. (2019). Hydrodynamics of DARPA SUBOFF Submarine at Shallowly Immersion Conditions. TransNav, 13(2), 337-342. https://doi.org/10.12716/1001.13.02.09

Farell, C. (1973). On the Wave Resistance of a Submerged Spheroid. Journal of Ship Research, 17(1), 111.

Farell, C., \& Guven, O. (1973). On the Experimental Determination of the Resistance Components of a Submerged Spheroid. Journal of Ship Research, 17 (1973): 72-79. https://doi.org/10.5957/ jsr.1973.17.2.72 
Gertler, M. (1950). Resistance Experiments On A Systematic Series Of Streamlined Bodies Of Revolution-For Application to the Design Of High-Speed Submarines (Report no. C-297). Navy Department David Taylor Model Basin, Washington D.C. Retrieved from https://apps.dtic.mil/dtic/tr/fulltext/ u2/a800144.pdf

Gertler, M., \& Hagen, G. R. (1967). Standart Equations of Motion For Submarine Simulation (Report no. SR-009-01 01). Navy Ship Research and Development Center, Washington D.C.

Gourlay, T., \& Dawson, E. (2015). A Havelock Source Panel Method for Near-Surface Submarines. Journal of Marine Science and Application, 14(3), 215-224. https://doi.org/10.1007/s11804-015-13195

Griffin, M. J. (2002). Numerical Prediction of the Maneuvering Characteristics of Submarines Operating Near the Free Surface (Doctoral dissertation). Massachusetts Institute of Technology, MA. Retrieved from https://dspace.mit.edu/ handle/1721.1/8327

Guanghua, H. (2013). An iterative Rankine BEM for wave-making analysis of submerged and surfacepiercing bodies in finite water depth. Journal of Hydrodynamics, Ser. B. $25.839-847$. https://doi.org/10.1016/S1001-6058(13)60431-X.

Havelock, T. (1931). The Wave Resistance of a Spheroid. In Royal Society (pp. 275-285). Royal Society. https://doi.org/https://doi.org/10.1098/rspa.1931.0052

Havelock, T. H. (1919). Wave Resistance: Some Cases of Three-Dimensional Fluid Motion. Proceedings of the Royal Society of London. Series A, Containing Papers of a Mathematical and Physical Character, 95(670), 354-365. https://doi.org/10.1098/rspa.1919.0014

Havelock, T. H. (1917). Some cases of wave motion due to a submerged obstacle. Proceedings of the Royal Society of London. Series A, Containing Papers of a Mathematical and Physical Character, 93(654), 520-532. https://doi.org/10.1098/rspa.1917.0036

Havelock, T. H. (1931). The wave resistance of an ellipsoid. Proceedings of the Royal Society of London. Series A, Containing Papers of a Mathematical and Physical Character, 132(820), 480-486. https://doi.org/10.1098/rspa.1931.0113

Hess, J. L., \& Smith, A. M. O. (1964). Calculation of Nonlifting Potential Flow About Arbitrary ThreeDimensional Bodies. Journal of Ship Research, (8), 22-44. https://doi.org/10.5957/jsr.1964.8.4.22.

Hoerner, S. F. (1965). Fluid Dynamic Drag: Practical Information on Aerodynamic Drag and Hydrodynamic Resistance. Brick Town, New Jersey, USA.: Published by the author.

Huang, H., Zhou, Z., Li, H., Zhou, H., \& Xu, Y. (2020). The Effects of the Circulating Water Tunnel Wall and Support Struts on Hydrodynamic Coefficients Estimation for Autonomous Underwater Vehicles. International Journal of Naval Architecture and Ocean Engineering, 12, 1-10. https://doi.org/10.1016/j.ijnaoe.2019.04.008

ITTC Specialist Committee. (2002). Final report and recommendations to the 23th ITTC, Recommended Procedures and Guidelines-Testing and Extrapolation Methods Propulsion, Propulsor Open Water Test. In Proceedings of the 23th International Towing Tank Conference (pp. 1-8).

Jagadeesh, P., \& Murali, K. (2010). RANS Predictions of Free Surface Effects on Axisymmetric Underwater Body. Engineering Applications of Computational Fluid Mechanics, 4(2), 301-313. https://doi.org/10.1080/19942060.2010.11015318 
Jagadeesh, P., Murali, K., \& Idichandy, V. G. (2009). Experimental investigation of hydrodynamic force coefficients over AUV hull form. Ocean Engineering, 36(1), 113-118. https://doi.org/10.1016/j.oceaneng.2008.11.008

Kırıkbaş, O , Kınacı, Ö , Bal, Ş . (2021). Sualtı Araçlarının Manevra Karakteristiklerinin DeğerlendirilmesiI: Manevra Analizlerinde Kullanılan Yaklaşımlar . Gemi ve Deniz Teknolojisi , (219) , 6-58 . Retrieved from https://dergipark.org.tr/tr/pub/gdt/issue/63160/877594

Kim, S. E., Rhee, B. J., \& Miller, R. W. (2013). Anatomy of Turbulent Flow Around DARPA SUBOFF Body in a Turning Maneuver Using High-Fidelity RANS Computations. International Shipbuilding Progress, 60(1-4), 207-231. https://doi.org/10.3233/ISP-130100

Liu, H., \& Huang, T. T. (1998). Summary of DARPA Suboff Experimental Program Data (Report no. CRDKNSWC/HD-1298-11). Carderock Division, Naval Surface Warfare Center, West Bethesda, MD. Retrieved from https://apps.dtic.mil/sti/pdfs/ADA359226.pdf

Liu, T. L., \& Guo, Z. M. (2013). Analysis of Wave Spectrum for Submerged Bodies Moving Near the Free Surface. Ocean Engineering, 58, 239-251. https://doi.org/10.1016/j.oceaneng.2012.10.003

Mackay, M. (2003). Estimation of Submarine Near-Bottom Hydrodynamic Loads and Squat (Report no. DRDC Atlantic TM 2003-078). Defence R\&D Canada-Atlantic, Canada. Retrieved from https://apps.dtic.mil/dtic/tr/fulltext/u2/a418585.pdf

Moonesun, M., Javadi, M., Charmdooz, P., \& Mikhailovich, K.U. (2013). Evaluation of submarine model test in towing tank and comparison with CFD and experimental formulas for fully submerged resistance.

Moonesun, M., Korol, Y. M., Valeri, N., Brazhko, A., \& Ursolov, A. (2016). Bottom Effect on the Submarine Moving Close to the Sea Bottom. The Journal of Scientific and Engineering Research 6(1), 106-113

Nematollahi, Ali \& Dadvand, Abdolrahman \& Dawoodian, Mazyar. (2014). An axisymmetric underwater vehicle-free surface interaction: A numerical study. Ocean Engineering. 96. 205-214. https://doi.org/10.1016/j.oceaneng.2014.12.028.

Pétillon, F., Bordier, L., Dauce, F., \& Maisonneuve, J. J. (2019). Shallow and Infinite Water Manoeuvring of Submarine: Integration of Computational Fluid Dynamics (CFD) in the Design Process.

Phillips, A. B., Turnock, S. R., \& Furlong, M. (2010). Influence of turbulence closure models on the vortical flow field around a submarine body undergoing steady drift. Journal of Marine Science and Technology, 15(3), 201-217. https://doi.org/10.1007/s00773-010-0090-1

Polis, C., Ranmuthugala, D., Duffy, J., \& Renilson, M. (2013a). Characterisation of Near Surface Effects Acting on an Underwater Vehicle within the Vertical Plane. Proceedings of the International Naval Engineering Conference (14-16 May 2013), Singapore, pp. 1-5.

Polis, C., Ranmuthugala, D., Duffy, J., \& Renilson, M. (2013b). Enabling the Prediction of Manoeuvring Characteristics of a Submarine Operating Near the Free Surface. Proceedings of the Pacific 2013 International Maritime Conference (7-9 October 2013), Darling Harbour, Australia, pp. 1-11.

Renilson, M. (2018). Manoeuvring and Control. In Submarine Hydrodynamics (pp. 33-118). Springer, Cham. 
Renilson, M. R., Polis, C., Ranmuthugala, D., \& Duffy, J. (2014). Prediction of the Hydroplane Angles Required due to High Speed Submarine Operations Near the Surface. RINA, Royal Institution of Naval Architects - Warship 2014: Naval Submarines and UUV's, Papers, (June), 147-153.

Salari, M., \& Rava, A. (2017). Numerical Investigation of Hydrodynamic Flow Over an AUV Moving in the Water-Surface Vicinity Considering the Laminar-Turbulent Transition. Journal of Marine Science and Application, 16(3), 298-304. https://doi.org/10.1007/s11804-017-1422-x

Saout, O. (2003). Computation of Hydrodynamic Coefficients and Determination of Dynamic Stability Characteristics of an Underwater Vehicle Including Free Surface Effects (Master's thesis). Florida Atlantic University, Boca Rotan, FL. Retrieved from http://fau.digital.flvc.org/islandora/object/ fau\%3A9849/datastream/ OBJ/view

Saout, O., \& Ananthakrishnan, P. (2011). Hydrodynamic and dynamic analysis to determine the directional stability of an underwater vehicle near a free surface. Applied Ocean Research, 33(2), 158167. https://doi.org/10.1016/j.apor.2010.12.003

Shariati, S. K., \& Mousavizadegan, S. H. (2017). The Effect of Appendages on the Hydrodynamic Characteristics of an Underwater Vehicle Near the Free Surface. Applied Ocean Research. Elsevier. https://doi.org/10.1016/j.apor.2017.07.001

Tahara, Y., \& Stern, F. (1994). Validation of an interactive approach for calculating ship boundary layers and wakes for nonzero froude number. Computers and Fluids, 23(6), 785-816. https://doi.org/ 10.1016/0045-7930(94)90066-3

Tolliver, J. V. (1996). Studies on Submarine Control for Periscope Depth Operations. Thesis Collection (Master's thesis). Naval Postgraduate School, Monterey, CA. Retrieved from https:// apps.dtic.mil/sti/citations/ADA318492

Tupper, E. C., \& Rawson, K. J. (2001). Basic Ship Theory, Combined Volume (5th ed.). ButterworthHeinemann. pp. 387

Uslu, Y., \& Bal, S. (2008). Numerical prediction of wave drag of 2-D and 3-D bodies under or on a free surface. Turkish Journal of Engineering and Environmental Sciences, 32(3), 177-188.

Vali, A., Saranjam, B., \& Kamali, R. (2018). Experimental and Numerical Study of a Submarine and Propeller Behaviors in Submergence and Surface Conditions. Journal of Applied Fluid Mechanics, 11(5), 1297-1308. https://doi.org/10.29252/jafm.11.05.28693

Wang, L., Martin, J. E., Felli, M., \& Carrica, P. M. (2020). Experimental and CFD for the Propeller Wake of a Generic Submarine Operating Near the Surface. Ocean Engineering, (206), 1-17. https://doi.org/https://doi.org/10.1016/j.oceaneng.2020.107304

Weinblum, G., Amtsberg, H., \& Bock, W. (1950). Test on Wave Resistance of Immersed Bodies of Revolution (Report no. 1950-09-01). David Taylor Model Basin, Washington D.C. Retrieved from https://apps.dtic.mil/sti/citations/AD0827201.

Wigley, W. C. S. (1953). Water Forces on Submerged Bodies in Motion. Transactions, Institute of Naval Architects, (95), 268-279.

Wilson-Haffenden, S., Renilson, M., Ranmuthugala, D., \& Dawson, E. (2010). An investigation into the wave making resistance of a submarine travelling below the free surface. In International Maritime 
Conference 2010: Maritime Industry-Challenges, Opportunities and Imperatives, 27-29 January 2010, Sydney, Australia (pp. 495-504). Engineers Australia.

Wu, B. S., Xing, F., Kuang, X. F., \& Miao, Q. M. (2005). Investigation of hydrodynamic characteristics of submarine moving close to the sea bottom with CFD methods. Chuan Bo Li Xue/Journal of Ship Mechanics. https://doi.org/10.3969/j.issn.1007-7294.2005.03.003

Zhang, J. T., Maxwell, J. A., Gerber, A. G., Holloway, A. G. L., \& Watt, G. D. (2013). Simulation of the Flow Over Axisymmetric Submarine Hulls in Steady Turning. Ocean Engineering, 57, 180-196. https://doi.org/10.1016/j.oceaneng.2012.09.016

Zhang, N., \& Zhang, S. L. (2014). Numerical Simulation of Hull/Propeller Interaction of Submarine in Submergence and near Surface Conditions. Journal of Hydrodynamics, 26(1), 50-56. https://doi.org/10.1016/S1001-6058(14)60006-8 